\title{
The Social Psychology of Violence on Children in an Urban School in Jamaica
}

\author{
Paul Andrew Bourne* and Enid McLymont \\ Northern Caribbean University, Manchester, Jamaica
}

\begin{abstract}
Introduction: Children living in violent communities across the length and breadth of Jamaica are particularly vulnerable to anti-social and criminal behaviours. Chuck [1] in his contribution on violence asserted that the present reality of violence has become the heaven for a wide range of emotional feelings ranging from discouragement, desperation, fear, anger, and depression which is not confined to any particular class or groups.
\end{abstract}

Aim: Therefore this study will concentrate on finding out how children who have experienced violence actually perform academically. The participants will be drawn from among fourth and fifth graders in a Jamaican primary school in an urban area. It is hope that this study will provide some insight for school administrators and stakeholders of the various strategies to which they can employ in correcting violence at school and changing the low academic performance of children who are exposed to violence in their communities.

Method: The data were analyzed using themes, and narrations, and they were presented in figures and tables as well as narratives of the participants.

Results: All the participants of the study stated that community violence range from the involvement of police officers and gang members, gang members and innocent community members, and internal as well as external gang violence. The two major themes emerged from this study are the 1) Gruesome acts of violence witnessed, and 2) Negative influence of witnessing violent acts.

Conclusion: A school with a robust process in place that routinely monitors students' behavior, consistently enforce the school's policies, and regularly communicate the expectations to staff, students, and parents can dramatically improve the quality of their school climate.

Keywords

Violence, Community violence, Academic performance, Home violence

\section{Background}

The issue of violent crimes has become pandemic in the Caribbean, especially Jamaica [2-5]. The crime phenomenon in Jamaica is so widespread that in 2007 a national probability survey that was done by [6] revealed that crime and violence were the leading problems identified in Jamaica. The statistics, showed that murder is the leading form of violence and that it continues to be a challenge to policy makers [7]. In another study done by Bourne, Hudson-Davis, Sharpe-Pryce...Nelson [8] found that 44.2 per 100,000 Jamaican was murdered in 2013 which makes this country the sixth with the highest number of murders in the world. In an empirical study conducted by [9-11] revealed that murder is linked to other health issues; and that there is a correlation between murder and poverty, ill health and violent crimes. According to Bourne and Solan [10] "The nexus of violent crimes in Jamaica goes back to pre-emancipation, when the revolt of the slaves would lead to their capture and murder" (p. 59), suggesting the long standing problem with crime and violence and survivability. Crime is, therefore, at a pandemic proportion in Jamaica, and it has infiltrated schools which is equally the case in other geo-political areas in the globe [12-16]. The reality, therefore, is children who are exposed in violence at their homes and/or communities are performing academically at a lower level than expected of them [14].

Children living in violent communities across the length and breadth of Jamaica are particularly vulnerable to an-

*Corresponding author: Paul Andrew Bourne, Northern Caribbean University, Manchester, Jamaica

Accepted: March 11, 2020

Published online: March 13, 2020

Citation: Bourne PA, McLymont E (2020) The Social Psychology of Violence on Children in an Urban School in Jamaica. Insights Anthropol 4(1):239-267 
ti-social and criminal behaviours [17-19]. Chuck [1] in his contribution on violence asserted that the present reality of violence has become the heaven for a wide range of emotional feelings ranging from discouragement, desperation, fear, anger, and depression which is not confined to any particular class or groups [20].

The passion to conduct this study came as a result of my close observation of many students who are exposed a high level of violence in communities such as St. Johns' Road, Homestead, Red Pond, and Irish Pen and how there is a high absenteeism among these pupils when violence erupts in their communities. In addition to their low academic performance. Besides the physical harm violence causes our children; there is also the psychological distress associated with it. It is important that the social environment be free from fear that children can feel safe. This is only achievable if the worsening trends of violence be eradicated in society. It is the belief of the researcher that teachers and students alike should be able to perform in a safe setting conducive to the teaching-learning process. Therefore this study will concentrate on finding out how children who have experienced violence actually perform academically. The participants will be drawn from among the grades 4 and 5 classes in a Jamaican primary school in an urban area. It is hope that this study will provide some insight for school administrators and stakeholders of the various strategies to which they can employ in correcting violence at school and changing the low academic performance of children who are exposed to violence in their communities.

Schools have been portrayed by many students and their parents as unsafe places, that are frequently characterized by rapes, shootings, stabbings, beatings, bullying, and other social deviant acts $[12,21,22]$; there is also reported cases of violence against teachers by students as well as their parents and associates $[17,18]$. These occurrences of acts of violence in the form of verbal threats, cursing, name-calling, or fights is more frequent in schools than homicide [15], making schools unsafe places for young minds. Grumpel and Meadan [23] stated that although there is widespread violence in schools, and it has been receiving much attention, there is still a lack of clarity as to what constitutes school-based violence. This, some believe, may influence the reporting of prevalence rates. Batsche and Knoff [16] stated that school violence is usually defined by acts of assault, theft, and vandalism or acts that may not be intentional but cause fear in either teacher or student. Gumpel \& Meadan [23] further classified aggressive behaviors as either acts that are clearly violent as in the case of those inflicting bodily harm or the psychological which consist of those including teasing, bullying, or name-calling.

\section{Statement of the Problem}

The research team as well as a family member has taught at schools in violent prone communities for over twenty years. Over the two decades, the school has had to close its door when violence commences in the surrounding communities. In fact, there have been many occasions in which the violence begins in the adjacent community and then is played out on the school's compound. There have been a few occasions in which students and teachers had to lay on the classroom floor for fear of life. Owing to what obtains sometimes during the nights children are unable to complete assignments because they must turn off the lights when the violence erupts in the community. In fact, there was one year in which the violence in the surrounding communities to the school affected examination including Grade Four Examination, and the Grade Six Achievement Test (G-SAT). During periods in which violence commences in the neighboring communities to the school, especially the adjacent areas to the school, there is heightened fear among teachers, students, administrators, and other staffers at the school. This leads to interruption of the functioning of the school, no teaching or learning can go on and syllabi are not completed for the specified time. The reality is, violence in school and the general community in which the school exists retards the teaching-learning process, and does account for the lower academic performance among pupils at a school.

A study conducted by Baker-Henningham, Meeks-Gardner, Chang, and Walker [24], investigated the experiences of violence and the deficit in academic achievement among a cross-section of urban primary school children in Jamaica and some potent findings were revealed thereby. Their study confirmed that there is a correlation between primary school children's experiences of three different types of violence (exposure to community violence, and exposure to aggression among peers at school), and their academic achievement. Such a finding provides a rationale for the researcher want to examine the role of violence on academic performance of pupils who attend a primary school that is situated in a violent prone community in urban St. Catherine.

\section{Methodology}

A research process constitutes identification of a problem, literature search, methodology and method, data collection, analysis of data, collation of the research, and so forth, with the methodology being a critical component of the process. Within the context of the previously mentioned issue, this research employed mixed methodologies - quantitative and qualitative methodologies. The rationale behind the mixed methodology is simply the drawbacks in one method can be enhance by the strength of another method. Many scholars [25-27] noted that mixed method lends itself to triangulation of findings, in-depth analyses and therefore is the best approach to the research agenda. For this research, the research will employ 1) Survey research - via a standardized questionnaire) and 2) Phenomenology - by way of elite interviews and/or focus group discussions.

\section{Purpose of the Study}

The primary purpose of this exploratory study is to explore reasons for poor academic scores and academic success among a group of fourth graders and to implement strategies to improve school performance. The population consists of students from the primary classroom and from this a purposive sample of ten will be selected for the in- 
tervention. The students live in violence prone communities in Spanish Town, St. Catherine during the period January 1-to-January 20, 2017. The researcher also informed the principal of one of the benefits of this intervention programme which is to help administrators to make meaningful decisions as to which teaching approach would best fit the subjects in order to improve performance.

\section{Main Research Questions}

How does community violence influence the academic performance of a group of primary school students who live in violence prone communities in Spanish Town, St. Catherine during the period January 1-to-January 20, 2017?

How does community violence influence the behaviour of a group of primary school students who live in selected violent prone communities in Spanish Town, St. Catherine during the period January 1-to-January 20, 2017?

\section{Significance of the study}

Harriott [28] posited that research is critical to effective policy formulation. His perspective provides the most significant basis on which this study is justified. It is anticipated that the information gleaned from this study will be used to sensitize parents, school administrators, guidance counselors, and teachers on the many problems facing children as a result of their exposure to violence.

The actual information garnered from this study will be made available to the Ministry of Education with the hope that it will influence the types of early childhood, primary, and secondary programme/curriculum planned by the Ministry of Education for schools. Secondly, that findings from this study will focus on the need for government to employ trained school psychologists beginning from the early childhood, primary and high school levels; to assist parents whose children will need to be tested.

\section{Limitations}

The use of non-probability sample means that the research is non-generalizable and as such the findings cannot be replicated to other samples. Nevertheless, the results for this study provide depth insight into a matter can be studied for a generable perspective.

\section{Operational definition of terms}

Gay and Arasian [29] stated that "operational" variables serve to clarify the meaning of important terms in a study so that readers will understand the precise meaning the researcher intends $(p, 64)$. The researcher is aware that there are other definitions for some of the terms used but wishes to clarify these used in the study.

- Violence: Is defined as behaviour involving physical force intended to hurt, damage, or kill and an infringements of basic rights, verbal and emotional aggression to inflicting physical harm [30,31].

- Family Violence: Is defined as any deliberate act intend- ed to harm members of the family whether be it physical, emotional or verbally [32].

- Child maltreatment: Includes neglect, physical abuse, emotional abuse or sexual abuse defined as inappropriate exposure of a child to sexual acts or materials, passive use of children as sexual stimuli for adults [33].

- Nature: Refers to the inherited or genetic characteristics of a person [33].

- Nurture: Refers to the characteristics of a person's environment that affect development [33].

- Family: People who are biologically related with each other.

- Community violence: Is defined as sexual assault, burglary, use of weapons, the sounds of bullet shots, as well as social disorder issues such as the presence of teen gangs, drugs, and racial divisions [34]. Retrieved from www.nccev.org

- Academic functioning: Is define as the child's ability to demonstrate or perform cognitive activities such as problem-solving, classifying, comprehension, written language communication, reading, mathematics and general information at the age appropriate content (adapted from the 1992 American Association of Mental Retardation, AAMR). For this study, it is measured by way of the evaluation of a standardized test. In addition, failure or poor performance is score below $60 \%$.

- Resilience in children: Is the ability of a child to respond to the realities of life's barriers and to use them as stepping stones to development and success.

- Temperament: Defines an individual behavioural style and the way of responding emotionally to any event [35].

\section{Summary}

Children are a product of their social milieu, which means that the underperformance of pupils at the primary educational level must a by-product of the general society. The underperformances of Jamaican candidates in Mathematics and English Language are clear indicators of violence in the home as well as the community including school. The complaints of managers about the quality of the human stock in Jamaica are in keeping with the general social confusions, role-crossing and deficiencies in expectations. The research by Powell, Bourne and Waller (2007) which identified the travails in the educational system in Jamaica is a wider social issue. Clearly, the answers to the underperformance of Jamaica students in various subjects must be tackled from a social context, and this study will provide the ingredients for such dialogue and actions. The dismally low performances of Jamaican primary school require urgent attention, and this research seeks to provide a social context for the matter and the way forward. This paper is sub-divided in five chapters with the remaining being literature review, methodology, findings and discussion of the findings in context with the literature as well some meaningful recommendations. 


\section{Literature Review}

The literature review sets the broad concept for examining the issues surrounding a particular theme, allows for the building block of research questions and provides a platform for embarking on new ideas [36]. Hence, this chapter, literature review, plays a critical role in the research process and cannot be excluded from a research. Therefore, this paper examines violence in environment including the community and home and how it influence academic performance of students. As time progresses, violence has increasingly become more prevalent in society and its tenets far reaching to include children. As a result, the family setting would feel some amount of the backlash. Violence is experienced in many forms. Instances of violence include sexual, physical abuse, emotion abuse, television violence, family violence and community violence. In an effort to establish transparency, the review will encompass five major captions. Namely:

1. The theoretical framework of the study

2. The consequence violence in the family has on children

3. The structure of the family as it relates to exposure to violence

4. Family Functioning and its exposure to violence

5. Is a child's academic performance impacted by experiences of family and community violence?

\section{Theoretical framework of the study}

Crotty [26] pointed out that the research process begins with an epistemology followed by a theoretical per- spective, methodology and method. He continued that the theoretical perspective is "The philosophical stance informing the methodology and thus providing a context for the process and grounding its logic and criteria" [26]. In keeping with Crotty's perspective, the researcher therefore employed a theoretical framework because of its significance to the research process. Hence, the ecological and nature versus nurture theories are used to form the theoretical perspective for the current work: 1) The ecological theory and 2) Nature verses Nurture theory.

The ecological model: In 1979, Bronfenbrenner developed a model which placed much significance on the role the environment plays in the development of a child. Based on his theory, the entire development of the child occurs through relationships experienced through a variety of environments that exists. The micro-system, meso-system, exo-system, and the macro-system forms the four pillars through which the child is believed to interact in. The most direct, interactive and influential environment is the micro system. This system covers the interaction between the child and family members, caregivers, religious setting, school and neighbors. The micro system is of such influence, that it can directly influence the formation of a child's personality negatively or positively.

The second of the four pillars is the mesosystem, which Santrock [35] thought it to be the relationship that exists in the micro-system. For example, parents lay the foundation of religion in the home. This is followed up by attending their place of worship at the appointed time based on that particular religion. The parent would give guidance and follow up the child's progress. In contrast to the connection of the

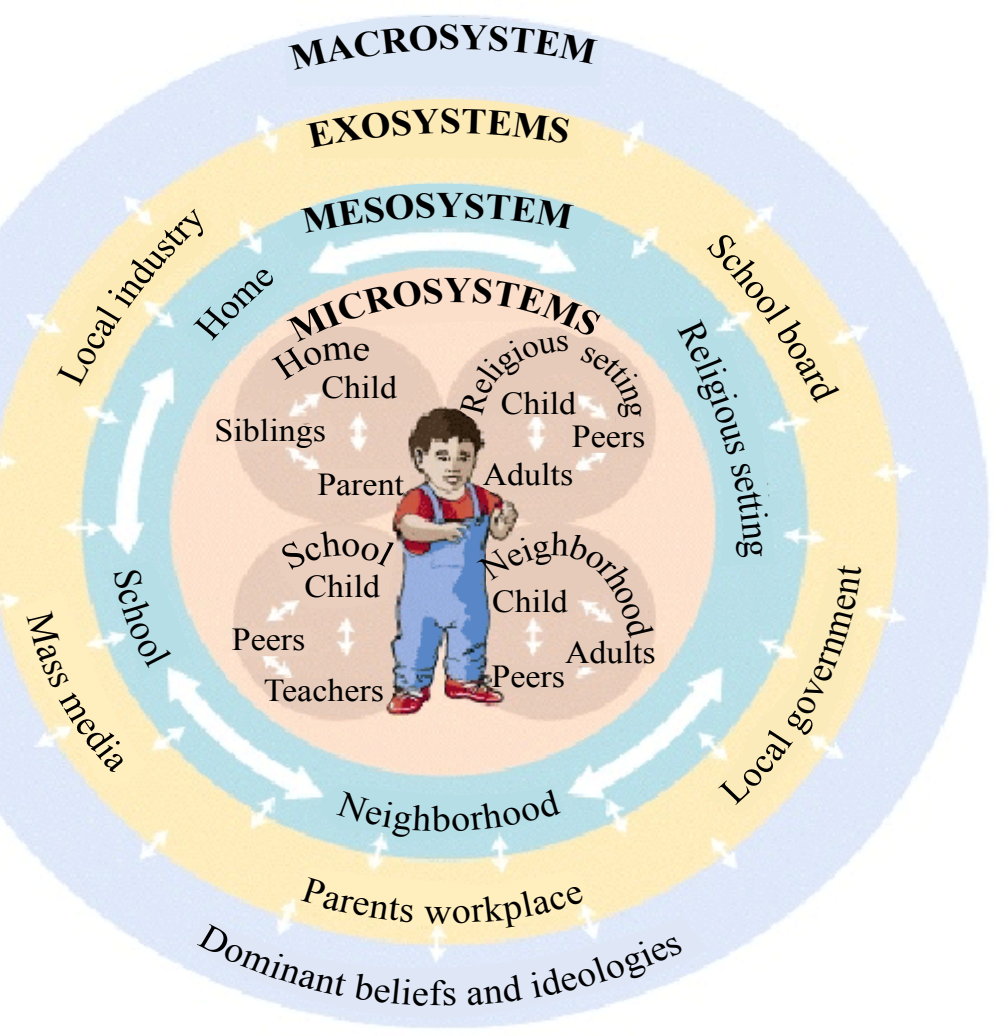

Figure 1: Ecological Model Smith \& Green, 2007. 
child's mesosystem, in accordance with the risk factors that are present, violent tendencies and behaviors might occur.

The third and penultimate pillar is the exosystem which speaks about the child's interaction with society. The child's role is an interactive one at best; however, it is the society that influences the child's experience. A child who lives in a very peaceful home for example is likely to relate to peers in the same manner. However, a child who has a father who is a gang leader in his community can be expected to display violent behavior.

The fourth and final pillar is the macro system, deals with the rite of passage. Values, attitudes and cultural norms are conveyed to the child by the general community. This also indirectly influences how the child interacts on a day to day basis with significant others. The home, school and community all provide influences for positive or negative patterns through interaction. All in all, the development of the child is assessed within the confines of an environment and the relationships within that environment. One must pay attention to all the factors of stress in the surroundings in order to grasp the concept of family and community violence. One can justify that the methodology within the confines of an ecological framework is most useful as it relates to child development (Figure 1).

Nature versus nurture theory: It was thought many decades ago that one's biological instinct was the major influence in an individual's behavior. It is now understood that one's behavior is as a result of the social environment that he or she encounters. Hereditary traits are what come to mind when one thinks about nature, while one's experiences in any given environment is credited to nature. This means that theoretical analysis is provided which deals with biological outlook as it regards to birth defects and the impact of cell development. Its analysis also extends to the impact that factors such as family dynamics, gender, parenting, school and neighborhood quality play in the development of the child and there temperament. So much so, that Malley-Morrison claimed that legitimacy is established in many cultures as rage and aggression are regarded as values which are displayed as strong biological components.

Santrock [35] went one step further as he made reference to Krause, Bronfenbrenner and Morris's claim. He did so by establishing an extension of one's biological environment which includes nutrition, medical care, drugs and physical accident. The interaction between both nature and nurture is of utmost importance in the developmental path of the child. This is especially noticeable in between mother and child. Collin and Seinberg states that an adolescent is less likely to become a drug addict or engage in acts of delinquency if he or she is effectively monitored by parents. Patterson [33] spoke about creating a perfect habitat student development. He added that harmonizing family school and culture would provide the optimal climate for students to achieve.

\section{The consequence violence in the family has on children}

Firstly, one must understand that family violence is one of the most prevalent acts in our society, and that everyone at one point or another is affected by it [36]. For an act of violence to be categorized as family violence, there must be a deliberate intent from at least one family member to harm another member of the family [37]. This may occur in the form of; child maltreatment, spousal abuse or abuse to the elderly. Wilson stated that isolation and hopelessness are often displayed by children who experience violence, regardless of what age they encounter it. He went on further to say that these children will also display acts of violence as a means of solving problems. He also went on to say that these children experience intense levels of anxiety and will ultimately experience retardation in their development. A year later Weihe [32] stated that academic disturbance may come into play if children are consistently exposed to violence. This according to Weihe [32] occurs because children loose considerable amounts of school time by trying to escape violence. Some children may attempt to run away, or move in with other family members, leaving behind documentations that are essential for school, such as; immunization cards and birth certificate.

Long term effects of violence on children who are exposed to it: The effects of violence on children are quite often neglected, especially when the child was not the direct target of abuse. However, post-traumatic stress disorder is quite common in children after exposure to violence. Such disorder includes; bed wetting, nightmares, insomnia, reduction in verbal, cognitive and motor abilities and depression $[34,38,39]$.

Short term effects of violence on children who are exposed to it: The short term effects of violence on children are easily identifiable traits. According to Wiehe [32] children who are exposed to violence are likely to perform poorly academically and tend to lose newly acquired skills. Isolation comes into play and the child develops a short attention span.

How community violence affects children: It is often said that children are like sponges. They are ready to absorb whatever lessons there are to learn. As such, they tend to imitate adult behavior. Acts of violence in communities include burglary, sexual assault, shootings, stabbings and extortion to name a few. These examples can often be found in schools, because in most cases children learn these practices in the communities first. Thompson and Massat [38] found in their research that children who were exposed to violence displayed some levels of post-traumatic stress. Chevannes's [40] in a local study found that boys who participate in violent activities pay an even higher price. His study showed that boys who are involved in community violence would stop participating in predictable activities, such as attending school, for fear of being pounced upon by other gang members on the road. It would also seem that the perpetual cycle of males participating in criminal activities will continue indefinitely according to Chevannes [40]. His study showed that fathers in many instances were forced to flee their communities for fear of losing their lives. This in turn leaves children fatherless. 


\section{The structure of the family as it relates to expo- sure to violence}

Much importance is placed on having a nuclear family throughout the Caribbean [41]. Despite this fact, there are many families with single parents in cohabiting unions, households with none biological siblings and children with none related guardians. It is not difficult to perceive that the quality of the home is crucial in the emotional development of a child. Cases where there have been one or both parents going abroad and leaving and older sibling in charge, tends to result in instances of physical and, or verbal abuse. The younger sibling will also fall short of the nurturing that is needed. This is due to the fact that older siblings, though seemingly responsible are ill-equipped to handle the pressures of parenting. It is in a family setting that a child first learns how to show affection. It is during this crucial period that the child learns right from wrong and their development can be a positive or a negative one.

\section{Family functioning and children's exposure to vi- olence}

One cannot assess family functioning and its exposure to violence without considering the psyche of the child. This is due to the fact that the child's first sociable interaction comes from within the family unit. It is through this interaction that self actualization is given birth. Children exposed to violence and dysfunctional family settings, usually become deviants [42]. These individuals would also display signs of low self esteem and high rates of psychiatric illness. The role of the family is of such importance, that it "exerts the greatest amount of influence on the lives of children" [17]. This is due to the fact that it is in the setting that values and attitudes are learnt and prejudices about themselves and others are displayed. Many researchers have come to realize that the family setting gives major insight as it relates to research on mental health.

Risk factors that contribute to students' involvement in violence: Risk factors relate to those characteristics of the person or the environment that are associated with an increased chance of maladaptive behaviour occurring. The contributors to violence in schools are viewed as a reflection of what takes place in the communities, the home, the media and the school environment. It should not be surprising then, that an increasing number of students are involved in violence in one way or another as victims or perpetrators. Social learning theory posits that people acquire aggressive behaviours through observing and imitating [43]. This shows that violence is a learnt behavior. Hawkins and Catalano [44] have identified several risk factors in young people that are predictors of later violence and antisocial behaviour. Among these factors was alienation which was linked to a lack of bonding to school, family and community stress. They believed that learning prosocial skills not only helped young people with their interpersonal relationships, but with their attitudes towards school as well. Such improvement would yield higher academic achievement and a more cooperative school climate. This would help to erase the negative and antisocial behaviour which students had. They stated that it was important not only to see the skills modeled but that they are practiced in a setting where feedback and reinforcement were provided for the choice of skills. In Jamaica there has been attempt by programmes such as Peace and Love in Schools (PALS) and Change from within which teach skills to deal peacefully with conflicts.

An article by Prevention Institute (2001) concluded that the frequency of an individual's exposure to risk factors predisposes him or her to the probability for increased engagement in violent behaviour. These were listed as individual factors, school factors and community factors.

Individual factors included poor academic performance, poor use of unstructured free time as well as delinquent peers. School factors had to do with the size of the school population, geographic location and gangs. The larger the school population the more likely it was for occurrence of violent acts. Schools situated in urban areas were more prone to report serious violent acts compared to those in more rural areas. In communities a lack of inadequate social amenities brought about a feeling of societal neglect by students. Their anger and frustration were vented by violence.

Violent behaviour was portrayed by the media as an appropriate way to solve problems. Young people therefore became desensitized to and accepted violence. The use of guns was yet another factor as the easy access to weapons increased its use. Like most other views expressed, students were most likely to be violent if they were witnesses of violence or were subject to childhood abuse. Students came to see the world as a dangerous place. To survive one had to be prepared to react to adverse situations which were always present. Such an attitude promoted a sense of defensiveness, suspicion, the need for standing one's ground and inclination to offer reprisal for the slightest offence.

Other underlying factors were poor financial situation, stressful family environment with lack of proper role models, conflict in the home and poor communication skills. Mental illnesses and mental disorders impaired students' ability to communicate and make right decisions. They were therefore at an increased risk of being perpetrators or victims of violence. Fernald and Meeks- Gardner [18] cited that in Jamaica although students are exposed to violence those in the inner cities are exposed to greater levels of crime and violence. These students prove to be more aggressive and resort to violence to settle their problems.

Leone, Mayer, Malmgren and Misel [45] noted that hyperactivity, limited attention span, restlessness, poor social skills favor the development of delinquent behaviour. The beliefs and attitudes of some students dictated that there should be retaliation for any and every situation. In addition students with certain disabilities for example emotional disturbances, Attention Deficit Hyperactivity Disorder and specific learning disabilities were more likely to display antisocial behaviours.

Conditions in the home provided early onset of chronic patterns of antisocial behaviour. These were linked to harsh 
and ineffective parental discipline, lack of parental involvement, family conflict, parental criminality, child abuse or neglect [14]. Williams points out that Jamaica is primarily a matriarchal society. The absence of fathers in many households negates positive parental values particularly to the males. The increasing number of teenaged mothers heightens the problem of children being given proper parental guidance.

Cole [46] believed that students were increasingly coming from backgrounds where antisocial behaviour was more the norm than the exception. The students were highly agitated and invested in antisocial attitudes and beliefs which made the use of antisocial solutions to interpersonal conflicts legitimate. They tend to see the behaviour and intentions of others as being biased against them. This bias helped to distort the ability to decode and interpret the social behaviour of others in a positive way. They frequently react aggressively to situations they view as challenging or threatening.

Shafii and Shafii [13] stated that children learnt to resolve their own problems through the use of violent strategies which they see being used. They imitate the behaviour of others and receive positive reinforcement from their peers when they deal with interpersonal conflict in a positive manner. Based on the background many children experience, some of them will resort to violence when they have exceeded their tolerance of frustration. Portrait reports that many of the young people report a history of violence in their lives. It is further reported that at sometime they thought about hurting or killing someone. This reinforces that when violence is experienced, whether as victim or perpetrator there is the increased risk that an adolescent will resort to violence against others.

Skiba and Peterson [47] showed that influences in the school and community helped to establish patterns of aggressive and violent behavior. Low school involvement, academic and social failure were some of the school factors named. There was failure to carry through rules as well as poor or inconsistent administrative support. In addition disciplinary practices in many schools were inconsistent and inequitable. Students from communities in which there was a lack of programmmes whether recreational or after school were prone to adopt violent behaviours. The absence of mentors helped to foster an adherence to antisocial behaviours. A lack of emotional or financial support may be gained through involvement in antisocial behavior.

Steinberg [48] examined the role of the family as a contributor to violent behavior in children. He stated that exposure to violence or abuse in the home, exposure to hostile punitive parenting or growing up in a home environment in which parents were not sufficiently involved in the child's life were among the most important risk factors for the child's subsequent involvement in violent and other types of antisocial behaviour. He looked at the role of the family from six perspectives. These are modeling, biological factors, and mental health, parenting personality development, academic performance and peer pressure.

Biological factors relate to early abuse and neglect. He pointed out that poor prenatal care, or pre-natal exposure to drugs could alter brain development. This led to some children having more difficulty containing aggressive impulses. Children whose parents were hostile and punitive as well as those whose parents were neglectful were at risk for developing all sorts of mental health problems. Children with mental health problems were at risk for developing patterns of antisocial and violent behaviours.

Negative parenting impaired proper personality development in children. They not only developed problems in controlling their emotions but also developed a biased way of looking at the world. They perceived that all people's actions were intentionally hostile when in fact they may not be so. Children who had problems in schools often gravitated towards groups of other troubled children and these peer groups frequently became involved in antisocial behaviour. Adolescents looked to their peers for support. It was easier to display antisocial or violent behaviour when with their peers that they would not do if they were alone. Adolescents who had strong positive relationships at home were more able to resist peer pressure. In contrast a lack of parental involvement or supervision placed the child at risk for involvement in antisocial peer activities and increased the youngster's vulnerability to negative peer influence.

He showed that adolescents who had the greatest number of problems with antisocial behaviour, personality development and in general mental health, came from families in which parents were hostile, aloof and involved. Many parents have abandoned their role and children are either left on their own or with relatives. Often these children do not learn positive values and resort to anti-social or delinquent behaviour.

Parental aggression, hostility and disengagement were good precursors of many problem behaviours. Children were more likely to show psychological problems both in terms of misconduct, and types of distress. They proved to be less interested and successful in schools. The television and other media were frequently blamed for today's epidemic of violence. The absence of fear, grief, remorse and consequences for violence on television, in movies or music sent a wrong message. They showed that violence was an acceptable way to solve problems as well as a symbol of power. The brutality depicted was unhealthy and even dangerous. Donnerstein, Slaby, and Eron stated that persons who viewed a lot of violence on television began to see the world as a mean and scary place where aggressive acts were acceptable means of solving problems.

Beresin stated that there appeared to be a strong correlation between media violence and aggressive behaviour. This he substantiated by stating that over the past 30 years longitudinal, cross-sectional and experimental studies had confirmed such a correlation. Children had access to television sets in their bedroom which facilitated the opportunity to view programmes without parental supervision. Heroes, the violent ones, were rewarded for their behaviour, becoming models for the youths. Children 
came to view violence as a fact of life became desensitized to it, ultimately losing their ability to empathize with either victim or perpetrator. The child rather than observing only became involved in acting out what is viewed.

Slaby maintained that violent students thought differently from their non-aggressive peers. Youths who were prone to violence sought fewer facts and had less insight into alternative solution. They often failed to anticipate the negative consequences of their behaviour. Violence in schools has several negative effects on students. Some of these are addressed in the next section. These students believe that if they are approached with violence they have to react violently otherwise they will be called derogatory names.

Impact of violence in schools: From the literature reviewed, violence in schools had varied and far reaching effects on students, teachers and the school system. The incidents of violence in schools not only posed a threat to the safety of teachers, students, and teachers but also proved to be a challenge to the authority of school administrators. Many teachers have been verbally abused, physically attacked or threatened by students or their relatives. If schools are to be safe there should be a lack of psychological stress and physical harm [49]. The antisocial behaviour of students endangered the safety of school personnel. Students and staff members suffered psychologically and physically because of violence in schools. Some incidents have been fatal.

It is believed that students feel powerless when attacked or provoked hence, they resort to violence when provoked in order to regain a sense of power [50]. This was evident in a series of school related shootings which took place in the United States. In schools in Jamaica incidents of shootings are few, the knife is widely used with frequent stabbings which occur, some of which are fatal. A report published by the $\mathrm{Na}$ tional Association of State Board of Education of Virginia in 1994 outlined some of the effects on teachers, students and the learning environment. The report recorded examples of the negative, physical, social, emotional, cognitive and psychological effects.

Students who were victims of violence may exhibit feelings of fear, anger, sadness, guilt, and mistrust. Violent or disruptive behaviour could destroy a positive learning environment. The fear that was generated by the acts of violence inhibited the ability of teachers to teach and students to learn. Cognitively the students who were fearful may have trouble paying attention, concentrating and learning. In order to ensure the safety of children, parents might keep children from school, thus affecting school attendance. Some may even be permanently removed. From a social point of view students who had either witnessed violence or been a victim may be either disruptive or aggressive and had difficulty relating to other students. Psychologically behavioural disorders may occur. Schools were prone to suffer from a lack of extracurricular activities as a response to campuses being unsafe. Violence in schools therefore interferes with optimal learning as an atmosphere of fear is established.
Bullying which frequently occurred in schools was often taken lightly but could have serious effects. Students who were bullied may suffer from depression, low self-esteem or anxiety. The fact that students may feel unsafe at school significantly interfered with learning. Schneider outlined the effects of bullying which he defined as purposefully doing harm to others. This was facilitated through ever repeating physical assaults, verbal and physical intimidation, harassment and constant molestation. The damage to the victim was of a mental nature rather than physical. The humiliation lasted for years, with the victims suffering from reduced self-esteem. This could affect academic and social outcomes. Victims suffered from emotional and psychological trauma and in extreme cases were lead to serious violence. Rigby [51] showed that students who had been harassed by peers had suffered depression and experienced suicidal ideation. Olweus [52] reported that students subjected to frequent bullying often sought refuge from teachers during breaks, avoided restrooms and other isolated areas or made excuses to be absent from school. They appeared distressed, unhappy and depressed with evidence of deterioration in interest and performance in school.

Boivin, Hymal and Hodges [22] showed that there was a relationship between peer harassment and academic performance. Victims tend to develop negative attitude towards school and overtime school performance declined. Dodge, Bates and Pettit [53] concluded from studies done that abused children tend to acquire deviant patterns of processing social information. This fostered the development of aggressive behaviours. Harmed children had a bias to attribute hostile intentions to others and a lack of positive behavioural strategies to solve interpersonal problems. These patterns were found to predict the development of aggressive behaviours. The experience of physical harm led a child to conceptualize the world in deviant ways that later perpetuated the cycle of violence. The viewing of television violence overtime helps to reinforce hostile thoughts which the viewer might have had [54]. The viewer always seems to be able to recall the violent scenes in a graphic manner.

Osofsky [55] reported that exposure to violence could have significant effects on children during older development and as they form their own intimate relationships in childhood and adulthood. Although literature was produced on the various developmental stages, the literature relating to adolescents was found to be most relevant to this study. She posited that evidence from research revealed that adolescents exposed to violence particularly those exposed to chronic community violence throughout their lives, tended to show high levels of aggression and acting out, accompanied by anxiety, behavioural problems, truancy, school problems, and revenge seeking. Children exposed to family violence often displayed internalizing and externalizing behavioural problems in comparison to children from non-violent families. Internalizing behaviours included withdrawal and anxiety while aggressiveness and delinquency manifested externalizing behaviours. Overall functioning, attitude, social competence 
and school performances were often affected negatively. Longitudinal studies according to the writer had revealed that children exposed to media violence overtime were most likely to engage in delinquent and aggressive behaviour. Media violence may increase negative behaviour because of the potential for social learning and modeling of inappropriate behaviour. Even when fictionalized violence that was dramatically portrayed and glamorized was likely to have negative impact on children and increased their propensity for violence. Television programmes and movies show graphic acts of violence as well as provide violent role models with whom adolescents can identify. By observing models in violent and aggressive behaviors the children react in a similar way. Many of the themes portray jealousy, revenge and violence.

The long term viewing of television violence does have a negative effect on students as with a preference for "action movies" they can be seen acting out what is viewed. It should be noted however that if properly utilized and if guidance is given during viewing the television can be used for educational purposes. Hawkins [44] addressed the aspect of resiliency. He defined resilient persons as those who were exposed to potentially damaging environments, events or circumstances during the course of their development they were either able to resist them or overcome the effects of the high risk conditions. They have been identified as possessing among other qualities strong social competence and problem solving skills. This demonstrates why some students although faced with risk factors which promoted violence do not become violent or aggressive.

Christle, Joviette and Nelson looked at certain protective factors which account for one to be exposed to risk factors but do not display aggressive and violent behaviour. Like risk factors, protective factors may be strengthened through interaction with other factors. These include individual, family, school and community factors. Individual factors include having a more positive view of one's life circumstances and stress reducing strategies. Family protective factors are viewed against the background that there is an attachment to at least one family member. This member not only provides a sense of belonging but shows the child that he or she is valued. In the schools both teachers and administrators can assist by providing a positive and safe learning environment. There should be the setting of high yet achievable academic and social expectation. These should be facilitated. Students should be encouraged to be members of groups in the school as this would help to deter demonstration of aggression or violence. The social structure in the communities could help to prevent students from engaging in antisocial and violent behaviour.

Strategies to decrease incidents of violence: In order to decrease the threat posed by violence in the schools, many strategies have been utilized. This range from punitive to the more humane ones which include counselling and the teaching of conflict resolution skills. Skiba and Peterson [56] outlined the many strategies, which were being implemented to help with the prevention or decline of antisocial or violent behaviour. These included the use of metal detectors, security guards, dress codes, zero-tolerance policies resulting in sus- pension or expulsion for certain types of aggression or threatening behaviour. Strategies for identifying students most likely to commit violent acts were formulated. The use of strong disciplinary tactics in response to disruptive behaviour was maintained.

Mulvey and Cauffman [57] stated that despite the violence which occurred in schools, these institutions had proven to be one of the safest places for youths. The fact that violence does occur in schools had led administrators to devise various strategies to stem the incidents of violence. Some of these they believed did more harm than good to the students. Their focus was on the strategy aimed at identifying and intervening proactively with potentially violent students. This they thought posed several challenges. The nature of the problem may have social underpinnings and to focus solely on the individual would not achieve the desired result. Adolescents they stated were still undergoing developmental changes hence their characteristics were not fully formed. They reported that although it was not clear which intervention worked, the ones which focused on building specific skills were more likely to work. There should be on going evaluation of the factors which increased or decreased the likelihood of one being violent. Students should be encouraged to give information on students who were facing problems or prone to violence. This could only be achieved however, if there was a supportive and healthy school relationship. This would foster a sense of belonging, and decrease any feeling of alienation. Students would then feel freer to give information. On the contrary students felt mistrusted and uninvolved when administration adopted a zero -tolerance approach.

Lantieri and Patti [58] described a programme which recognized that the ability to manage emotions, resolve conflicts and alleviate biases were fundamental skills to be taught. Schools which were viewed as being able to perform a socializing function in students were able not only to nurture their thinking abilities but to practice handling their emotions learn how to deal with conflicts and gain exposure to societal values. To achieve this however, the skills for improving emotional competence should be taught.

Norguera [59] stated that the search for solution has generated many strategies. Some of these were coercive and harsh while others were more humane. There had been a preference however for the harsher ones in an effort to maintain authority, power, and control. Some of the more popular measures include the enactment of zero tolerance policies which serves to remove students who are involved in violent acts. The methods used are through suspensions, suspensions or transfers. Besides the use of these strategies, violent act or even non violent ones are treated as criminal offences. Despite the drastic approach being taken schools were still unsafe. The use of coercive methods interrupted learning and produced an environment of mistrust and resistance. Although schools had undertaken less coercive measure such as mentoring and the teaching of conflict resolution skills. The introductions of conflict reso- 
lution programs were instituted to teach students to settle their disputes in a non-violent manner. Through the use of adults as role models students are counseled and provided with a supportive environment.

The focus however is on the use of harsher methods. The contention was that violence must be countered with force. For schools to be safe it was assumed that they have to be like prisons, to identify, apprehend and get rid of students who are potential perpetrators of violence. In an effort to highlight the success of the various methods statistics are used to show the number of weapons confiscated and students expelled or suspended. The strategy employed was either to quantify the result of their effort or not to present at all, the latter being used because a lack of information being transmitted would suggest that violence was under control.

The extent of violence in schools in Jamaica: A study by Soyibo and Lee [12] among high school students revealed that $27 \%$ of the participants had caused injuries to persons, $59.5 \%$ used weapons and techniques during violent acts including use of hands or feet, $59.1 \%$ used nasty words, $54.5 \%$ used punches and kicks, $26.5 \%$ used blunt objects, $18.4 \%$ used knives, 9.3\% used ice-picks, $8.9 \%$ used machetes, $8.5 \%$ used scissors, $7.5 \%$ used forks, $6.9 \%$ used guns, other weapons (bottles and dividers) $6.7 \%$ and $5.5 \%$.

Callender who conducted a study in schools in Jamaica's capital found that $70 \%$ of students had seen fights in which a weapon was used. The knife was the most frequently used. $32 \%$ of students had been hurt in fights and needed treatment by the teacher. $50 \%$ of students reported that other students had deliberately damaged their property. Meeks-Gardener [60] found that $83.7 \%$ of a sample of 1710 knew children who took weapons such as a knife to school. $80 \%$ said children in their class fought a lot and were worried about violence at school. $40 \%$ reported that students threaten teachers with violence. $21 \%$ reported that students have actually attacked teachers at their school.

The Jamaica Teachers Association, the body which represents the nation's teachers has constantly voiced concern regarding the present spate of violence in schools. Several factors have been put forward. These include presence of gangs, violence in communities, extortion of students by students, lack of furniture, shoot outs in garrison communities and a lack of proper fencing. Incidents reported to the Association revealed that between September 2002- May 2003 fourteen teachers were attacked by students, three by the community and twelve teachers suffered injuries on the job. Over this same period twenty-eight students were attacked by other students, eight by members in the community, while thirteen were injured at school. Three students were killed at school over this period (J.T.A. Reporter, p 24). As impressive as the above statistics might appear they do not reveal a true picture of the extent of the violence that takes place as not all incidents are recorded. Most often, the more serious incidents are the ones which are recorded or gain public attention. Incidents of violence in schools occur on a daily basis, whether it is bullying, quarrels or fights.
Evaluation of strategies implemented to decrease incidence of violence: Although there is evidence to show that punitive methods have been widely used, studies have shown that they are not very effective means dealing with violence. In some cases it is thought that it exacerbates the problem. Suspension and expulsion are seen primarily as increasing the risk of disruption of one's education and eventually dropout and delinquency [61]. Mayer and Leone [62] believe them to be ineffective and may actually increase school disorder. Skiba and Peterson [61] stated that relying on zero tolerance for school safety teaches that in order for there to be safe schools their rights and liberties will have to be suspended. This gives rise to troubled youths. Di Giulio [51] believed that rather than schools educating and teaching skills of socialization, they have adopted methods, which were more legal in nature. The student offender in his opinion received a sentence of expulsion or suspension from the school setting. He stated that when teachers carefully constructed a classroom environment which modeled respect and trust students would have a laboratory for learning to interact in a positive and safe environment.

He contends that punitive measures gave rise to violence as they only relocate the problems. Schools protected their image with a "get tough" policy. Aggressiveness required intervention rather than relocation. There should therefore be reconsideration of the dismissive, punitive measures. Like other studies he agreed that schools relied on after the fact remedies. There should be more education to foster prosocial behaviour in order to counteract antisocial behaviour. Most often disruptive behaviour was considered to be a problem of the individual. Instead the social environment or context of the conflict should be examined. An understanding of the conflict would inform more appropriate or effective intervention.

Ascher [21] was critical of the methods being used and referred to the schools as "fortresses." He thought that schools were more of a garrison type in which not many teachers felt at ease despite the concerns for safety. He stated that rather than offering reassurance, metal detectors, other mechanical devices, as well security forces were seen as providing a false sense of security. It was a symbol of failure to create safe schools. Sophisticated devices could not detect all the weapons entering a school, as it was not easy to secure every entrance to the school. The methods extracted a significant portion of the budget and served to increase rather than alleviate tensions in the schools. This was endorsed by Skiba and Peterson [61] who believed that although the measures may improve safety they impact negatively by creating an atmosphere of fear and intimidation.

Flannery [63] reported that some methods undertaken were short, "quick fix" methods or sophisticated multifaceted long term programs. Many were successful but some were not. Lack of success was due to the programmes being developed without evidence of the potential for their effectiveness. The evaluation of the program was crucial for assessment and improvement. Assessment should continue during 
the period when the program was being implemented. This would facilitate changes to accommodate new developments and improve outcomes.

Data from a study conducted by National Association of Social Workers (2001) revealed that students who gained knowledge and skills in resolving conflicts were able to apply the skills to conflict situation. They chose more assertive and less aggressive responses to situations after they had received conflict- resolution training. The programme was effective in reducing both overt and covert conflicts. Students resolved conflicts on their own by using the skills learnt. The social workers reported less referrals, or referrals requiring less conference time to resolve.

Smith and Sandhu [64] reported that most policies were seen as punitive rather than edifying. Most of the approaches were problem focussed in that they targeted negative behaviour as opposed to building alternative prosocial skills. In addition the majority of the strategies were reactive in the sense that they occurred in response to undesirable behaviour. The strategies instead should proactively operate to prevent the occurrence of such behaviour. A sense of connectedness between students, peers, family, school and community should be fostered. This would reduce the likelihood of students becoming engaged in negative and antisocial behaviours.

The measures, although sometimes effective, had negative effects. These included the placing of a significant financial burden on limited school funds, a reduction of time for classroom instruction and a decline in teacher and student morale [65]. Curwin and Mendler [66] were critical of the zero-tolerance policy being applied to every type of violent act. It was considered to be unfair as the same treatment could not be meted out to every problem. A denial of one's education for relatively minor reasons was viewed as a violation of one's rights in a democratic society.

Steinberg [48] stated that the main reasons for schools failure occurred outside the school and classroom. The ability of school to deal with the larger problem was limited because of the effects of larger social factors. Schools on a whole tended to disregard the contributing forces outside the boundaries of the school. The factors included parental disengagement from students' lives and their performance, activities, which competed with academic performance and exposure to a variety of risk factors. Stanley, Juhnke and Purkey [67] stated that violence programmes were defined to reduce violence without addressing school culture, academic achievement and existing student, parent and faculty concerns. The programmes appeared to treat symptoms instead of causes. Although it was possible to create a school where everyone felt safe it would be representative of a fortress rather than a school. Schools they believed should be both safe and conducive to academic success.

A prison-like atmosphere it was reported could create an atmosphere of apprehension and coercion. Instead programs should be proactive and preventative. The teaching of skills to mediate conflicts, such as peer mediation and conflict resolution proved to be useful. In an effort to in- crease safety and student success the use of group and individual counselling were advocated.

Casella [68] focussed on the use of zero tolerance policy in schools. He reported that zero tolerance policy attempted to prevent violence by punishing young people because of their potential for or display of violence. He further stated that the policy could create blockades for all students. It provided the addition of another risk factor to lives that were already overburdened with risk factors. Some students by the support they have may be able to manoeuver their way back to success after an expulsion or suspension. Not all students are afforded such privilege. Expulsion therefore, takes on different meaning when one student who is expelled can afford tutoring and another is not able to do so. The conclusion is that the consistent application of the policy does not mean that all students receive the same punishment. Schools needed well-developed discipline policy which should not only attempt to solve the problem of violence. Such policy should ensure that no student was "derailed" from his or her education or put in circumstances that increase the likelihood of criminality in the future. It was stated that a failing aspect of zero tolerance was that it steered youths from school property to various outplacements and sometimes into prisons. The policy was used to deal with mild offences it was never initially meant to address. Violence prevention and discipline policies should deal with the context of situations. The nature and history of conflicts, the relationship between those involved and the meaning that people make of situations are all part of that context. Students should be kept involved in school, be held accountable with the availability of a safe school. Help should be provided to students with the greatest difficulties. It is evident that use of suspensions or expulsions as a means of curtailing school violence. They do not achieve the desired result or solve the problem of violence. There was however, failure of the studies to show the perceptions of the students to being expelled or suspended. This is important, as some students prefer not to be in school. Students after returning from a suspension sometimes continue with the same type of antisocial behaviour as before.

\section{Methodology}

\section{Introduction}

The current study undertakes to examine violence in environment including the community and home and how it influences academic performance among a group of fourth and fifth graders from an urban area primary school. The purposes of the study are 1) To fulfill the requirements of a Doctor of Philosophy in Education degree majoring in leadership, and 2) To aid policy makers and administrators by providing empirical facts that can be useful in enhancing learning outcomes of pupils in violent prone schools. This chapter will give an overview of the research design, and the sample size used in the research. The chapter will also speak about the data collection procedures, limitations, a description of the instruments used, and how the data will be analyzed. Ethical consideration, validity and reliability are also components of this 
chapter. This study employs mixed methodology to carry out a research into violence and academic performance - positivism (i.e. survey research) and phenomenology.

\section{Positivism and post-positivism}

Historically, scientific inquiry was based on logic, precision, general principles, principles of verification, the standard of rigor, gradual development, "search for truth" and proofs. The proofs were critical to the pure sciences before the establishment of laws, principles, theories and apparatuses. Traditionally, science therefore, was guided by positivism. Positivism holds itself to (i) The collection of quantitative data, (ii) Separation of the researcher from the research process, (iii) Objectivity, (iv) Measurability, (v) Generalizability and (vi) Repetition. Thus, when the social science was born, the researchers embodied inquiries using the same approaches as the pure sciences. It follows that what was known about human behaviour had to be discovered through positivism and/or logical positivism. Social sciences like the natural sciences, was guided by logic (the study of valid forms of reasoning), metaphysics, the fundamental finds of things that really exist and the justification of knowledge (epistemology) which saw experimentative research been widely used to conduct inquiries. Science therefore was about the study of truth and not meanings. Why people do things, (i.e., meaning) was not important in research it was rather about the discovery of truth.

While empiricism is responsible for plethora of germane and critical discoveries that have aided humans' existence, it fails to explore potent things about people. Peoples' behaviours are not predictable, stationary, and while some generalizability exist therein, the 'whys' (meanings) are still unasked with the use of empirical inquiry (or objectivity and measurability). Qualitative inquiry mitigates against some of the inadequacies of objectivity, provides rich data on humans' experiences, and aids in a total understanding of people $[27,69-72]$. Thus, qualitative inquiry should not therefore be seen as an alternate paradigm to quantitative inquiry, but as a member of the understanding apparatus. This supports Schlick argument that we cannot know the truth without knowing the meaning (p.15).

Max Weber was the first to argue that an 'Interpretivism' approach can be employed in the examination of social phenomenon. Weber opined that why human behave the way they do is lost in quantitative methodologies (or positivism). He therefore, forwarded the use of subjectivity (feels, beliefs or meanings) in social inquiry. For years, the inquiry of social phenomenon was based on objectivity until Weber introduced an alternative paradigm. This gave rise to the emergence of (i) Ethnography, (ii) Phenomenology, (iii) Case study, (iv) Grounded theory, (v) feminism, (vi) Biography, (vii) Historical comparative analysis, and other methodologies (discourse analysis, heuristic inquiry, action research) were in keep with an alternative paradigm in scientific examination as approaches in understanding human behaviours.

\section{Phenomenology}

One scholar (Thomas Kuhn) argued that science not only embodies objectivity, logic, precision and general principles as humans are social beings [70]. As such, we must understand the meaning behind their behaviour which cannot be found by the use of objective methodologies. This gives rise to the use of subjective methodologies. One such subjective methodologies which is long established in the literature is ethnography $[27,69,71-73]$.

Ethnography is one of the methodologies in qualitative research that evolved from revolution of science. It focuses on the everyday behaviour of people (their interactions, language, ritual) in order to determine inter alia, cultural norms, beliefs and social structures (Leedy and Ormrod, 138). It is the "naturalistic observations and holistic understandings of culture or subcultures" (Babbie, 282) or the "art and science of describing a group or culture" [40]. In ethnography, the researcher "adopts a cultural lens to interpret observed behaviour, ensuring that the behaviours are placed in a culturally relevant and meaningful context". Thus ethnography is concerned with the meaning and/or interpretation of groups within its natural settings.

Ethnography is wildly used by many scholars to examine different cultural happenings in a society or sub-groups: Chevannes [40] used this approach to determine socialization of males in the Caribbean; Gayle used ethnography to determine how adolescence survive in violent communities in St. Catherine; Levy [74] employed this methodology to examine how people survive in urban violent community; and Schlegel and Barry examined sex role differentiation and segregation. The methodology is also used extensively in studies of organizations and, in particular, to examine behavioural issues such as those of law enforcement officials. The examples here are Westmarland who examined "witnessing of illegal police violence" in Britain; Behr who explored "behaviour and the thinking of officers...possession of powers and their discretion for using it" and Haanstab, who examined order in the Thai Police Force. Organizations have culture and patterns of behaviour. And, as Silverman [27] notes, they are fertile field for the ethnographer.

The issue under investigation is also a phenomenon, and this requires a phenomenological methodology that will utilize case study as the method of analysis [26]. In keeping with the phenomenological methodology and case study method, narration will be used to present the information as well as theme identification.

\section{Interviews-face-to-face}

Semi-structured face-to-face interviews were chosen as they were closest to the unstructured interview which is flexible, iterative and continuous as well as more likely to yield information that were not planned for Semi-structured faceto-face interviews allow for systematic and consistency while giving sufficient latitude for the subject to 'digress' thus enabling a deeper probe [71] and facilitating new and unexpected information. The use of semi-structured (instead of structured) format study enabled the researcher to make deeper 
probe into the issue-An inquiry into the perceived effects of community and family violence on the academic functioning amongst a group of grade four students at a school in a violent prone community in Spanish Town, St. Catherine.

The face-to-face interviews took the form of a "guided conversation" where the interviewees were seen not as "passive conduit for retrieving information", but more for interpretation and perspective thus facilitating a deep probe. The interview schedule has various semi-structure questions for the study. The intended time for each face-to-face interview would be twenty-minutes.

\section{Focus group}

From a listing of prospective participants-students whom had returned their Consent Form to the office-the researcher arbitrarily selected fifteen students to meet with a discuss the issue of violence and its effect on their performance. The students were brought into an enclosed room with an external supervisor whose function was to ensure ethical standards and decorum was adhered to in the room. On average, the focus group discussion should last for $\mathbf{3 0}$ minutes. A tape recorder was monitored by an independent person. Another person was the note taker and this division of labour was done because the researcher wanted to ensure that all the information was obtained and that no one person was assigned to more than one task. The note taker will be carrying out a verbatim recording of the spoken words by each student.

\section{Document reviews}

The researcher reviewed written documents such as statistics, documents from the Ministry of Education and Culture, written relevant literature on violence and academic performance and newspaper articles. A major reason for the document review was to assist in triangulating [75] and validating information obtained in the interview, given that interviews "rarely constitute the sole source of data in research" [76].

\section{Research design and sampling}

The research design for the present work is an exploratory one in which the researcher team relied on subjective perspectives of participants and no objectivism will be employed. The research was conducted using a non probability approach - purposive and snow balling sampling approaches was used to ascertain the sample for interviews or focus group sessions. The population was chosen solely based on two criteria. These are 1) Attend a particular primary school in Spanish Town, St. Catherine; 2) Less than 12-years-old; and 3) Reside in a violent prone community. Thus, participants who fulfilled those criteria were part of the sample. There were eleven participants-four from grade 4 and five from grade 5 .

The nature of this study is such that, the researcher chose participants based on their willingness to participate in the research process and them meeting the conditions for inclusion in the study in order to meet the general objective of the work-purposive sampling [77]. As such, participants who are not cognizant of the issues of this research could offer any assistance and therefore were not used [73]. Thus, fifteen (15) participants were either separately interviewed by the researcher or interviewed in a collective setting (i.e., focus group).

Having outlined to the various stakeholders-principal, vice principal and teachers-the researcher provided the classroom teachers with the requirements for selection (i.e., conditionality) and they then set up a meeting like that of a Town Hall setting. The researcher informed the students of the nature of the study, and they he seek their assistance in participation. However, they were informed that their participation or non-participation is totally based on a written consent from their parent, guardian, or custodial caregiver. A Consent Form was given to each student in a sealed envelope and they were asked to have them sign and returned on or before the next four weeks. The students were asked to give all signed Consent Form to a secretary in the Administrative Office.

\section{Study setting}

An urban government operated primary school is the target of this study. The school's population accounts for two thousand ranging from ages six to twelve years old. The grades that constitute the school's population are 1-to-6. The majority of students who attend the school are from poor socio-economic background and violence is a common occurrence on the school grounds. For this research, the participants were chosen from grade four. A quiet room was selected to conduct the research. This room was in close proximity to the guidance counselor's office. It was secluded and provided complete privacy, so as to create an environment where the children could feel safe in expressing themselves truthfully. As such, no teachers, administrators, and/or ancillary staff were invited or attended these for an in order to give the students an opportunity to openly express themselves with fear of reprisal from the school's personnel.

\section{Pilot study}

One of the philosophical assumption of knowledge is that one has is the solely holder of truth, wisdom, understanding and experience in this vast and complexed socio-physical world $[26,77]$. As such, requesting assistance from expert in the field; other authorities; and pilot testing instrument goes a far way in understanding the final quality of the items. Hence, the researcher consulted research books such as Basics of Quality Research by Anselm Strauss and Juliet Corbin [78]; Qualitative inquiry and research design: Choosing among five approaches by John Creswell [77]. The Practice of Social Research $10^{\text {th }}$ ed. By Earl Babbie [73], and Social Research Methods: Qualitative and Quantitative Approaches, $6^{\text {th }}$ ed. By William Neuman [69] as they provided some conceptual and technical guide in research process, especially itemizing questions for an instrument. One of the recommendations by all of the aforementioned methodologists is piloting testing the actual instrument in order to ensure readability, understandability, validity of the items, and most of all does the items actually measure the intended research question. In within the recommendation of the scholars, I seek to comply with this in order to improve the quality of my research. 
The instrument was tested on a few students at Northern Caribbean University who are unlikely to be selected in the final sample. Pilot testing was done to validate as well as to ensure reliability of the data gathering instrument. The instrument was piloted with fifteen respondents from a similar population that was not likely to be a part of the actual sample for the study. The exercise is estimated to last for thirty-to-forty five minutes. The respondents were coded and put into the computer. This was done to determine the validity, reliability and internal consistency of the items. Modifications were made to the initial instrument based on the feedback given by the supervisor/methodologist as well as the actual piloted respondents. The input was fed back into a modified instrument to formulate the final questions.

\section{Data analysis}

Three concurrent actions are pertinent in the analysis of

Table 1: Socio-demographic characteristics of the Sampled Respondents, $\mathrm{n}=11$.

\begin{tabular}{|c|c|c|}
\hline Details & $n$ & Per cent \\
\hline \multicolumn{3}{|l|}{ Age group: } \\
\hline $10-11$ years & 11 & 100.0 \\
\hline $12-13$ years & 0 & 0.0 \\
\hline $14+$ years & 0 & 0.0 \\
\hline \multicolumn{3}{|l|}{ Gender: } \\
\hline Male & 5 & 45.5 \\
\hline Female & 6 & 54.5 \\
\hline
\end{tabular}

\section{Area of Residence:}

\begin{tabular}{|l|l|l|}
\hline Red Pond & 0 & 0.0 \\
\hline Homestead & 0 & 0.0 \\
\hline St. John's Road & 3 & 27.3 \\
\hline Other & 8 & 72.7 \\
\hline
\end{tabular}

\section{Academic Performance:}

Mathematics, Mean \pm SD, $95 \% \mathrm{Cl} \quad 50.7 \% \pm 18.5,38.3 \%-63.1 \%$

Reading, Mean \pm SD, $95 \% \mathrm{Cl} \quad 64.8 \% \pm 16.1 \%, 54.0 \%-75.6 \%$ qualitative data: Data reduction, data display and conclusions and verification [71]. In this research, an equal amount of raw data taken in note form as well as tape recordings was retrieved during the interviews. For the qualitative aspect of the study, the researcher utilized a thematic approach [26] in focusing, simplifying, transforming thus reducing the voluminous raw data into different themes (or social constructions). Having formulated a variety of themes, they were then used to shape the format of the presentation of findings (narrative, summative) which later informed conclusions and verifications. In cases where respondents were asked to rate a particular event, these were presented in a tabular form.

\section{Method of analysis}

The methods of data analysis were 1) Research questions, 2) Themes, and 3) Narrations. The researcher collected data from observation on naturally occurring behaviors in their usual context through the detailed record keeping of events, feelings and conversations of participants as well as their non-verbal communication expressions. Responses from the instruments were analyzed in order to develop percentage frequencies, charts and narrations.

\section{Summative Model of Research}

Table 1 below indicates the research questions and the methods used to gather information (Table 2).

\section{Recording procedures}

The researcher will employ a professional audio engineer. The audio engineer will institute a microphone system in the room. He will wire each participant with a small microphone that will be placed on their person. The microphone will transmit the spoken words in a system that records the information on a tape. The engineer will be seated at the back of the room, monitoring the quality of the audio and he will only interject in the discussion if the quality of the record falls below an acceptable level. On completion of the session, the audio engineer will remove the microphones from each participant, remove the equipment and machines from the room and supply the researcher with a tape of the recorded session with the participants in interview as well as the focus group

Table 2: Summative perspectives on literature, methods, research questions and items on instrument.

\begin{tabular}{|c|c|c|}
\hline Research Questions & Sub-Research Question & Method \\
\hline \multirow{3}{*}{$\begin{array}{l}\text { How does community violence impact } \\
\text { on the academic performance of a } \\
\text { group of primary school students who } \\
\text { live in violence prone communities in } \\
\text { Spanish Town, St. Catherine during the } \\
\text { period January 1-to-January } 20,2017 ?\end{array}$} & $\begin{array}{l}\text { 1. Please tell me about times when you have seen or heard of violence } \\
\text { occurring in your community? }\end{array}$ & I, FG \\
\hline & $\begin{array}{l}\text { 2. Please share with me the memories you have of violence in your home } \\
\text { (including parents' quarreling with each other)? }\end{array}$ & I, FG \\
\hline & $\begin{array}{l}\text { 3. How would tell me about the times you have seen violence in your } \\
\text { community? }\end{array}$ & I, FG \\
\hline \multirow{2}{*}{$\begin{array}{l}\text { How does community violence impact } \\
\text { on the behaviour of a group of primary } \\
\text { school students who live in violent } \\
\text { prone communities in Spanish Town, } \\
\text { St. Catherine during the period January } \\
\text { 1-to-January } 20,2017 \text { ? }\end{array}$} & $\begin{array}{l}\text { 4. When there is a violent outbreak in your community, please describe how } \\
\text { feel when you have to study and do work in school. Tell me about the } \\
\text { grades you get and whether you are able to do well in school? }\end{array}$ & I, FG \\
\hline & $\begin{array}{l}\text { 5. When there is violence in your school share with me how you act and what } \\
\text { goes through your mind? Compare for me how your behavior and action } \\
\text { change from when there is no violence in school? }\end{array}$ & I, FG \\
\hline
\end{tabular}

I denotes Interview, and FG indicates focus group. 


\title{
Analytic Strategies for Analysis Qualitative Research
}

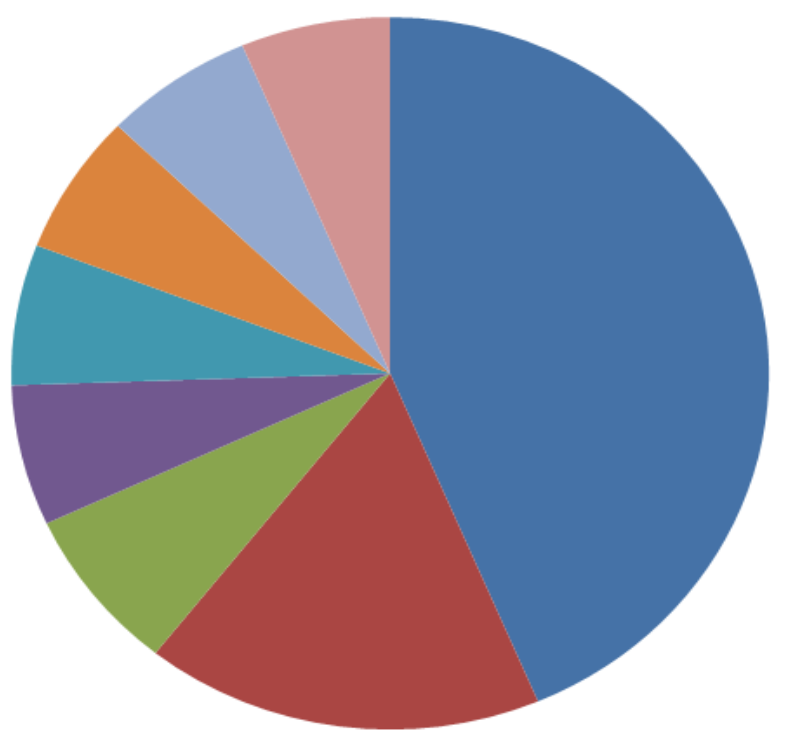

\author{
- Questioning \\ Making comparisons \\ Using the flip-flop techniques \\ - looking at language \\ lookint at emotions that are \\ expressed \\ using other analytical tools \\ making use of life experiences \\ Thinking about the various \\ meaning of words
}

Figure 2: Constructed from the readings of Saldana, Creswell \& Dainty, et al.

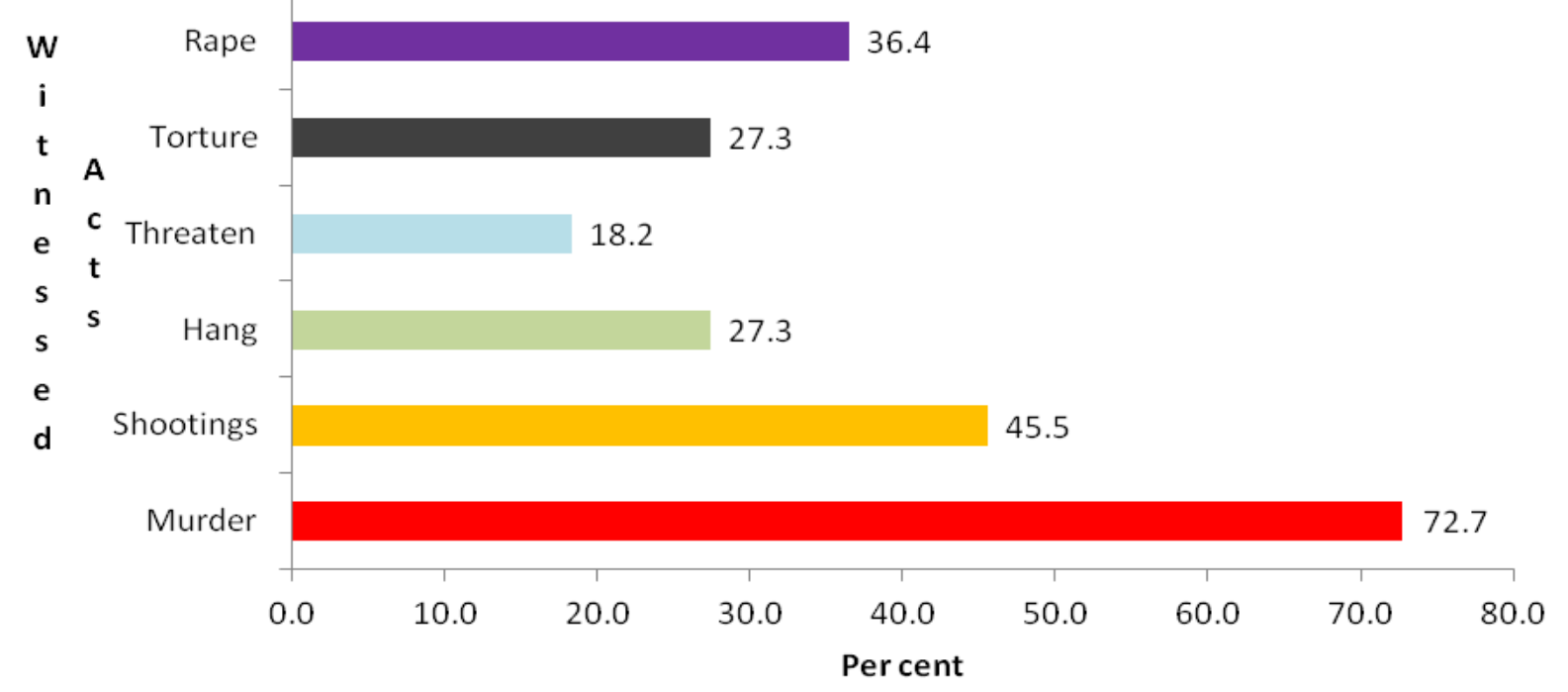

Figure 3: Witnessed Acts of Violence in Community.

discussion.

\section{Descriptions of analytic strategies}

Having reviewed and read Creswell [77]; Strauss, A. and Corbin, J. [78]; Dainty, et al. [79] Saldana [80] and other scholars, I have designed a graph that depicts some of the analytic strategies that are needed by the researcher prior to analysis qualitative data. The strategies are captured in Figure 2.

Strauss and Corbin [78] believed that the analysis of qualitative data must be within the context of meaning from words. Because interpretivist social science-frequently referred to as qualitative research [26] which was developed by
Max Weber [81-83] is about people's expressions, thinking, meaning system, and constructions of reality, it is critical for those who seek to engage in this research paradigm to understanding how data can be analysed by way of the different strategies (see Figure 3). Strauss and Corbin [78] opined:

Meaning is not inherent in words. Words take on meaning when they are given so by users (participants in the case of research) and readers. Analysis involves working with dat. Analysis is the act of taking data, thinking about it, and denoting concepts to stand for the analyst's interpretation of the meaning intended by the participant. 


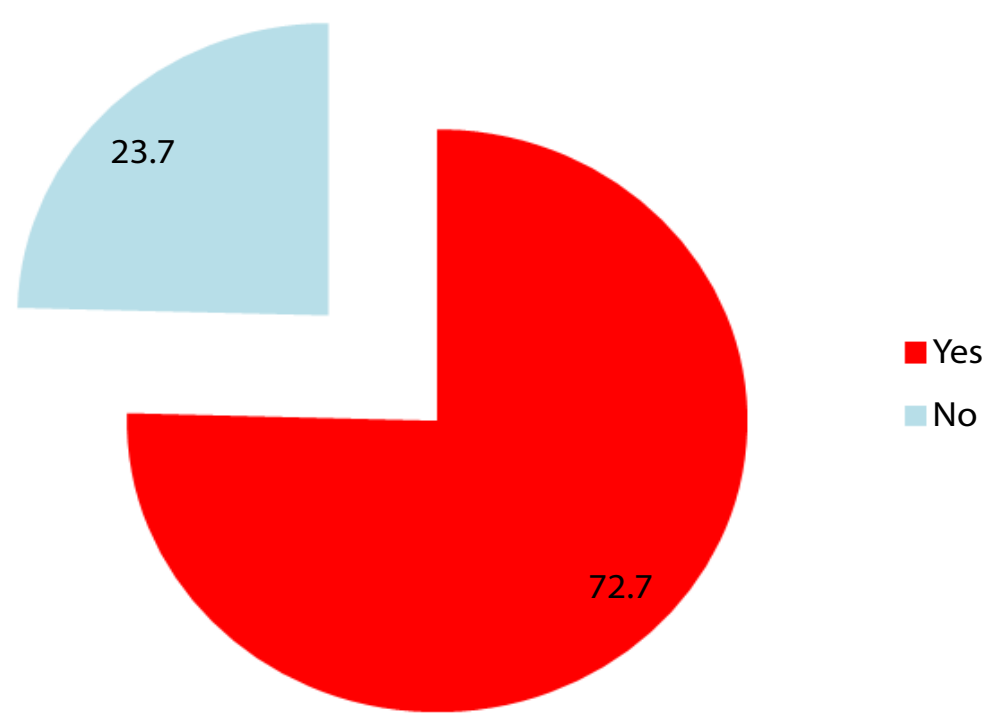

Figure 4: Students' Involvement in Physical Conflicts (or fights).

A researcher can think of analysis as "mining" data, digging beneath the surface to discover the hidden treasures contained within. Here is how Miles and Huberman [84] referred to coding and its relationship to analysis: "to review a set of field notes and to dissect them meaningfully while keeping the relations between the parts intact is the stuff of analysis" (p. 59 in Strauss and Corbin, [78] p. 88). Hence, a clear picture of the people's meanings, thinking, value system and expression can be understood by the researcher if he comes to the data mining process with the right questions (i.e. questioning). Because words have no meaning without a context, which is based on other people's context, then the researcher must make comparison of words with other people in order to grasp a better understanding of the written or unwritten expressions of people. The researcher needs to think about the various meanings of words; make use of his/ her life experiences in an attempt at understanding the meanings in people's expressions. Furthermore, the researcher needs to examine motives and emotions of people, use various analytical tools, and dissect these via the necessary and appropriate questioning. As such qualitative research's depth is built around the researcher's interpretation and perspective of reality. Those analytical strategies identified in Figure 4 are brought by yours truly to analysis this study. It should be noted here that a qualitative study must commence with a clear purpose for the study followed by definition of the scope of the research; develop research questions from the clear purpose and nature of the inquiry; and the development of research objectives from which will logically followed appropriate analytic tools.

For this study, the researcher travelled the strategies of the literature and this allowed for the smooth transition from philosophical perspective to framework to method, and finally the completion of the research paper.

\section{The analytic tools}

Among the various tools (or methods) of analyzing qualitative data are 1) Computer aided software such as ATLAS.ti for Windows and Mac; 2) Coding and classifying, 3) Thematic network, 4) Narrations, 5) Displaying data, and 6) Immersion/ crystallization. The researcher collected data by way of interviews and focus group discussion, feelings and conversations of participants were recorded on audio tape, transcribed in note form as well as the transcriptions from a note taker on the discussions. Responses from the instruments were analyzed using percentages, frequencies, charts, and narrations. The utilizations of percentages, frequencies and charts were used to provide readers with a clear sense of the degree of the issues, easy understanding of the phenomena, a visual display of the matters and importantly different analytic tools in keeping with the diverseness of the readers and the employment of many approaches as a result of what is learnt in the course, Advanced Qualitative Research II.

In this research, an equal amount of raw data taken in note form was retrieved during the interviews and by way of the focus group. Based on Creswell and Crotty some of the analytic tools for qualitative aspect of the study themes in focusing, simplifying, transforming thus reducing the voluminous raw data into different themes (or social constructions). Having formulated a variety of themes, they were then used to shape the format of the presentation of findings (narrative, summative) which later informed conclusions and verifications.

\section{Results}

Table 1 presents data on the socio-demographic characteristics of the sampled respondents (i.e., students). Of the sampled respondents, $45.5 \%(n=5)$ were males compared to $54.5 \%(n=6)$ being females. The majority of the sample resided outside of the neighbouring communities to the school (72.7\%, n = 8), with $27.3 \%$ dwelled on St. John's Road (i.e., adjacent to the school). The distant communities were Kitson Town, Point Hill, Villmore, Greater Portmore, Bylas, Frazer's Content, Mendez and Bellevue Heights. The average performance in mathematics was $50.7 \% \pm 18.5 \%$ compared to $64.8 \% \pm 16.1 \%$ in reading. 


\section{Research Question One}

From the qualitative elite interviews with both the Guidance Counselor and the students, the researcher was able to list a number of causes of students' antisocial behavior. These were socialization (home and community violence); psychological trauma and fear, and victimization.

\section{Acts of witnessed violence}

Figure 3 depicts the typologies of witnessed acts of violence in the community by participants. The majority of the participants have witnessed a murder $(72.7 \%, \mathrm{n}=8)$ and shootings ( $45.5 z \%, n=5)$, with a few having witnessed a rape $(36.4 \%, n=4)$. All the participants indicated that the witnessed violence in their community has adversely affected their behaviour. "You must defend yourself in my community, because you will be considered as soft and preyed upon" a male participant said.

The typologies of social deviance were truancy, usage of expletives (i.e., bad words, foul language, or curse words), physical conflicts, avoidance of classes, and walk out of classes without teacher's consent as well as irresponsiveness to authority.

Figure 4 depicts the per cent of students who are involved in physical conflicts or fights. The majority of the sampled respondents indicated that they were involved in physical conflicts either at school or in their communities.

When they were asked if they were involved in physical conflicts, the participants gave arguments like 'they dis me' [meaning, disrespected by the other person], bullied, a prevention of further bullying and disrespect. They also indicated that they experienced difficulty complying with what obtains at school. The closest explanation that emerged on the reason for the antisocial behaviour linking it to what socialized violent culture was by a male-participant who indicated that "I day-dream at school, find myself outside of class and do not want to go, violence can break out any time in my community." He continued that "I am easily frustrated, confused, and don't want any to dis me [disrespectful], so I act in order to prevent being dissed." As such, this means that the students are not concentrating on what obtains at school and this even made worse when violence erupts during the school day in the communities adjacent to the school.

The Guidance Counselor, 20 years' service at the schools, on the other hand, made a clear connection between social deviance exhibited by students and violence in their communities. The students who have experience social problems at home or their community, such as violence, are oftentimes disrespectful to authority, resist from performing classroom task including class work and home work. The Guidance Counselor indicated that it is oftentimes during counseling sessions with many of the students that it is discovered that the social problems (violence in the home or community) is internalized by the students and they act out this by way of their actions such as avoidance of classes, walk outs, physical conflicts, and failure to respond in class. Many of the students who experienced community violence act out what obtains at school, oftentimes boisterous, rebellious, and disrespect- ful to students. "Many strategies are employed to address the social deviant acts exhibited by the students and some have modified their behaviours," The Guidance Counselor remarked. She continued, "Many of them are experiencing psychological trauma and their behaviour is totally as a result of the socialized environment. The environment is primarily responsible for the social deviance of the students and mere suspension or expulsion cannot address the problem." Clearly, the social environment in which the students live is contributing to their deviant acts in an outside of school as well as inability to concentrate on school related activities.

\section{Research Question Two}

The two major themes emerged from the data to provide a response for this research question are 1) Gruesome acts of violence witnessed, and 2) Negative influence of witnessing violent acts.

Gruesome acts of violence witnessed. The sampled participants gave detailed accounts of violent acts that they have witnessed or that have occurred in their area of residence. All the participants of the study stated that community violence range from the involvement of police officers and gang members, gang members and innocent community members, and internal as well as external gang violence. Lionel (pseudo name) witnessed a brutal gang murder. "One day I was babysitting and saw five men, tie a rope around and throw a big stone on the man's head" Lionel said. He continued that "the man was left to die and my mother called the police. Lionel recalled a personal incident and during his recollection, he paused and then relate the occasion. "One night my parents were walking about mid-night. Somebody called my father and said someone was looking for him. Then, a man pointed a gun at him and asks "who are you?" The man with the gun shot at my father. My father told my mother to run. She ran and about 10 minutes after, I heard a shot. Early in the morning, I saw my grandfather body on the ground".

Other gruesome cases were reported by the participants of this study. Rochelle (pseudo name) recalled a vicious murder. "I was lying down when I heard gun shot in the cook shop. Two men got shot and fell to the ground. I saw the two bodies, and one was in the gutter". Tori (pseudo name) reported an incident that happened with her mother and her friend. "In the presence of my mom, a man used a shovel and hit her friend on the head. My mom's girlfriend fell to the ground".

Sian (pseudo name) gave a second hand account of an incident that happened in the presence of his mother. "My mother was walking one day when a man who was in front of her was killed. My mother said, a man took a gun from his waist band and shot a man. She said I ran towards the rubbish bin and fell therein. The man was fatally shot and he lay on the ground".

Paul (pseudo name) gave an account of a brutal incident with a family member. "My father sent my cousin to shop. While he walking, he saw a man with a long gun. One of his cousins came out and a man stopped him, he used a block 
and hit him in the face. The man with the gun fired a shot in the church's window" Paul said. He continued that "One day a man shot at my brother, my bother shot the back and the man was hit in the hand". Paul did not say whether his brother was a law enforcement officer; but, it appeared that he was not.

Simone (pseudo name) said "I was walking one day when a man pushed a stick wrapped with wire in the throat and neck of another man. He tied the man on a tree, took off his clothes and tied his private parts. The man's private part was chopped off and he was left for dead".

Other participants gave account of seeing dead bodies on the ground following police shootings. Violet (pseudo name) remarked "One day I was going to Children's Fair (Saturday morning), when I heard gun shots. I ran into a church. After a time, I came out to see the body of a man I knew on the ground. The ambulance was called by the police and some men were taken to hospital suffering from gunshot wounds".

Participants gave account of being victims of physical abused in their communities. "A girl hit me with a coconut on my head. I hit her back and a fight developed" Michelle recalled. She continued that her cousins, god sister, and father were shot in the head. They died on spot. Michelle explained that, "One day, my father was gambling on the roadside when a man in black, camp up to him and said 'wa a gwan'. He looked up. The man said, do what you have if do and done. Then, shot him in his feet first. My father said, just finish it. Then, the man shot him in his head. I was hurt and by friend fainted. My smaller brothers and sisters will not know their father".

All the participants indicated different psychological trauma experienced from witnessing and being exposed to community violence. The negative psychological conditions were more intense among those who had personal cases such as family members including fathers.

Like the participants, the Guidance Counselor made some revelations that concur with accounts of the participants. She explained being knowledgeable of gangsters who have murdered people, witnessed seeing gangsters with illegal guns, witnessed shootings, heard of people being raped, also known of cases where police have killed gangsters and that the community is a violent one. "Violence can erupt at any time" She said. The Guidance Counselor opined that "Violence has erupted on many occasions while I'm at school and school's operations were significantly hampered".

The witnessing of violence is a social reality for participants at this school, and there are instances when violent acts are perpetrated against even teachers. There is ample evidence that even the teachers are cognizant of those who are perpetrators, and this undoubtedly has some psychological impact on their wellbeing, particularly when they are at school.

\section{Research Question Three}

In an attempt to triangulate the influence of violence on students' behaviour and academic performance, an elite interview was conducted with the Guidance Counselor of the school. It can be summarized from the Guidance Counselor's viewpoint that 1) Violence has negative influence on students' behaviour, 2) Exposure to violence and academic performance are inversely related, and 3) Strategies employed by the school to address social deviant acts. The Guidance Counselor indicated that the following strategies have been employed to deal with antisocial behaviour exhibited by students at the studied school. The strategies were music, storytelling, games, drama, research, role playing and counseling. She remarked that while some antisocial behaviour emerged on a regular basis, the occurrence would have been more and a likeliness of other things being done if those strategies have been used. Drama and role playing along with storytelling are some of the strategies that have been employed by the guidance department and positive benefits have been observed. The students who exhibit social deviant acts when placed

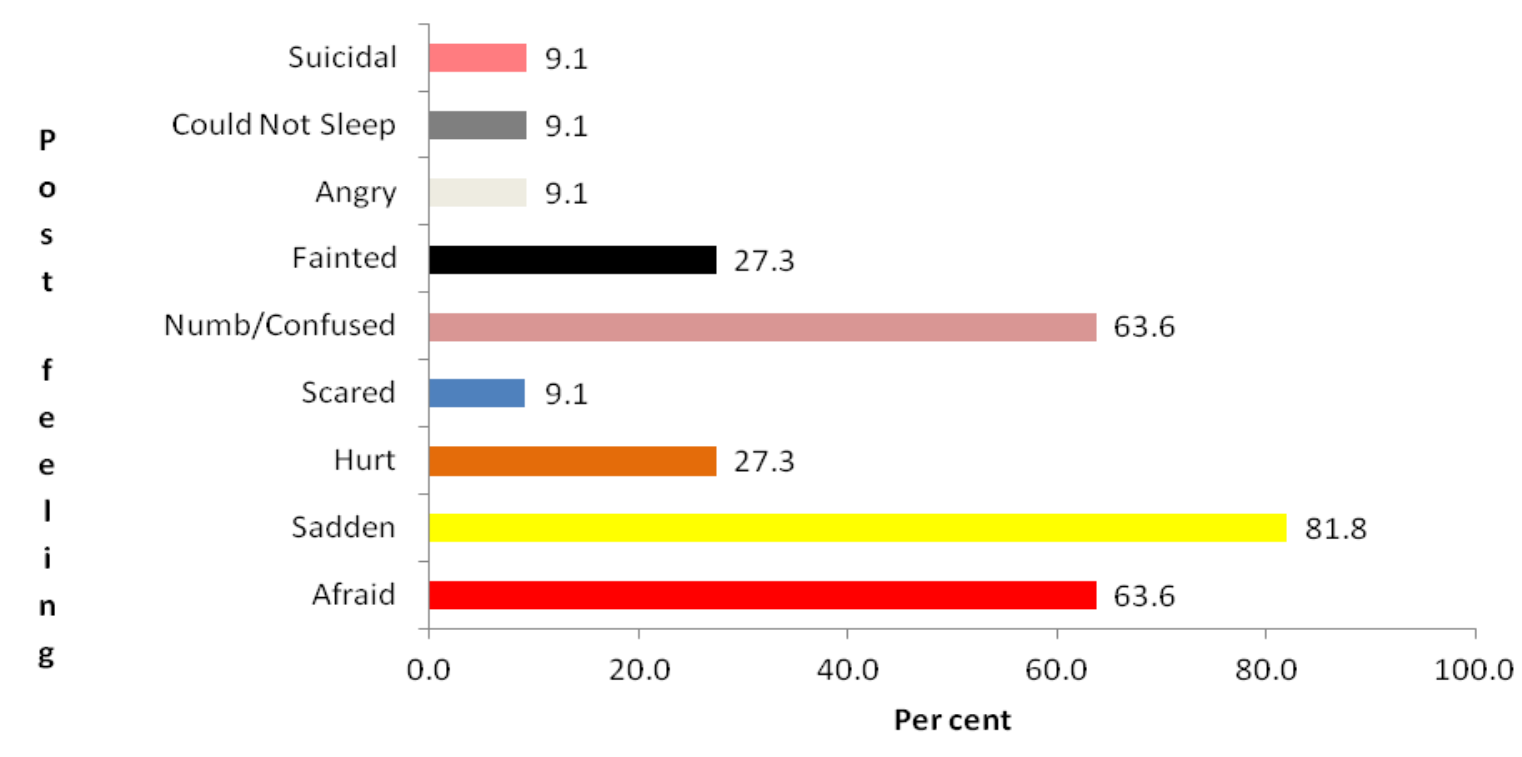

Figure 5: Students' feelings following a witnessed violent act. 
Citation: Bourne PA, McLymont E (2020) The Social Psychology of Violence on Children in an Urban School in Jamaica. Insights Anthropol 4(1):239-267

Table 3: Students' Perception on the influence of violence on academic performance.

\begin{tabular}{|l|l|l|l|}
\hline Details & $\mathbf{n}$ & $\mathbf{\%}$ & $\mathbf{n}(\mathbf{\%})$ \\
\hline No & 1 & 11.1 & $1(11.1)$ \\
\hline Yes & 8 & 88.9 & $8(88.9)$ \\
\hline Total & 9 & 100.0 & $9(100.0)$ \\
\hline
\end{tabular}

through the various strategies become less boisterous, rebellious and disrespecting of their peers as well as their teachers. Even among the new converts, there have been outburst, deviant acts and disrespectful tendencies; but the occurrences are usually lower than when nothing was done. "The teachers have reported changes in some of the students and while they indicated no change in other, we have been making significant strides in behaviour modifications of psychological challenged students" She said.

\section{Research Question Four}

The participants reported that violence in the community and/or home has an influence on their physical and psychological state. The words used by the participants to describe the influence of violence in the community and/or home clearly indicate the psychology of violence on young people. The participants' psychology of violence are captured in words like 'suicidal', 'sadden', numb, and confusion to describe post-feeling having witnessing a violent act. In addition, the negative influence of witnessed violence on academic performance was also articulated by the participants.

In order to understand how community violence affects the academic performance of those students who witnessed these act, they were asked how they felt following witnessing a violent act (Figure 5). The majority of the sampled participants used words like sadden $(81.8 \%, n=9)$, numb/confused $(63.6 \%, n=7)$ and afraid $(63.6 \%, n=7)$ to express how they feel following witnessing a violent act in their community. One participants stated that she felt suicidal (9.1\%) and another indicated that he could not sleep (9.1\%). A male-participant stated that "I peed myself on hearing gunshots". But that was not all as actually defecated in my pants!" The psychology state of many of the sampled participants is captured in their expressions of feelings following a violent act witnessed in the community.

Clearly the negative influence of the witnessed act of violence on the academic performance of the children is easy to make such a link. When they were asked "Do you think violence affect your performance at school?" the majority of them stated yes $(88.9 \%, n=9)$ - Table 3. A participant remarked that she cried, experienced difficulty concentrating, oftentimes anxious and numb and so her grades have fallen. Some participants used words like numbness, worry, wondered and fret while at school on what is like to happen at home. A participant said "I am spaced out" at school and it is affecting my performance at school. Simone (pseudo name) remarked that she is day-dream at school that "I am going to die one day in a fight." She continued that "my day-dreams are always in the forefront of my mind and so my grades have fallen".

All the participants indicated that they are unable to concentrate at school, especially in class. A male-participant said "whenever I hear gunshots, I pee himself". He "I am unable to concentrate at school, I am day-dreaming about violence in my community, I feel weak and do not know why I can't stay one place for long." He indicated that is a low perform; "but I can do better if I could just concentrate or sit down for some time to do my school work".

"I can't go outside because of gunshots in the community. I fear outside in the community. My uncle fights his wife and a police had to discharge his firearm for him to stop and this happened at my home. It is difficult to study in my home and my community, violence. I know, I am able to do much better in school; but I am unable to revise or do assignment at home" Sian (pseudo name) said.

Paul (pseudo name) mentioned that "My grades are low because I am unable to concentrate as I am low on energy, highly confused and easily frustrate. There is too much violence in my community. I'm tired of it".

In an elite interview with the Guidance Counselor, she reported that community violence inversely affect the performance of many students. She indicated that the communities close to the school are violent prone and that gunshots have been heard many times while at school. The Counselor indicated that school has been disrupted on many occasions following community violence and that school had to close on some occasions. She rated violence in the community at a moderate level and this explains why many of the pupils are poor performers in school work. The Guidance Counselor of the school has worked at the school for the past two decades and indicated that she has witnessed people being physically abused by gangsters, including seeing gangsters with guns.

\section{Research Question Five}

Clearly the negative influence of the witnessed act of violence on the academic performance of the children is easy to make such a link. When they were asked "Do you think violence affect your performance at school?" the majority of them stated yes $(88.9 \%, n=9)$ - Table 3. A participant remarked that she cried, experienced difficulty concentrating, oftentimes anxious and numb and so her grades have fallen. Some participants used words like numbness, worry, wondered and fret while at school on what is like to happen at home. A participant said "I am spaced out" at school and it is affecting my performance at school. Simone (pseudo name) remarked that she is day-dream at school that "I am going to die one day in a fight". She continued that "my day-dreams are always in the forefront of my mind and so my grades have fallen".

All the participants indicated that they are unable to concentrate at school, especially in class. A male-participant said "whenever I hear gunshots, I pee himself". He "I am unable to concentrate at school, I am day-dreaming about violence in my community, I feel weak and do not know why I can't stay 


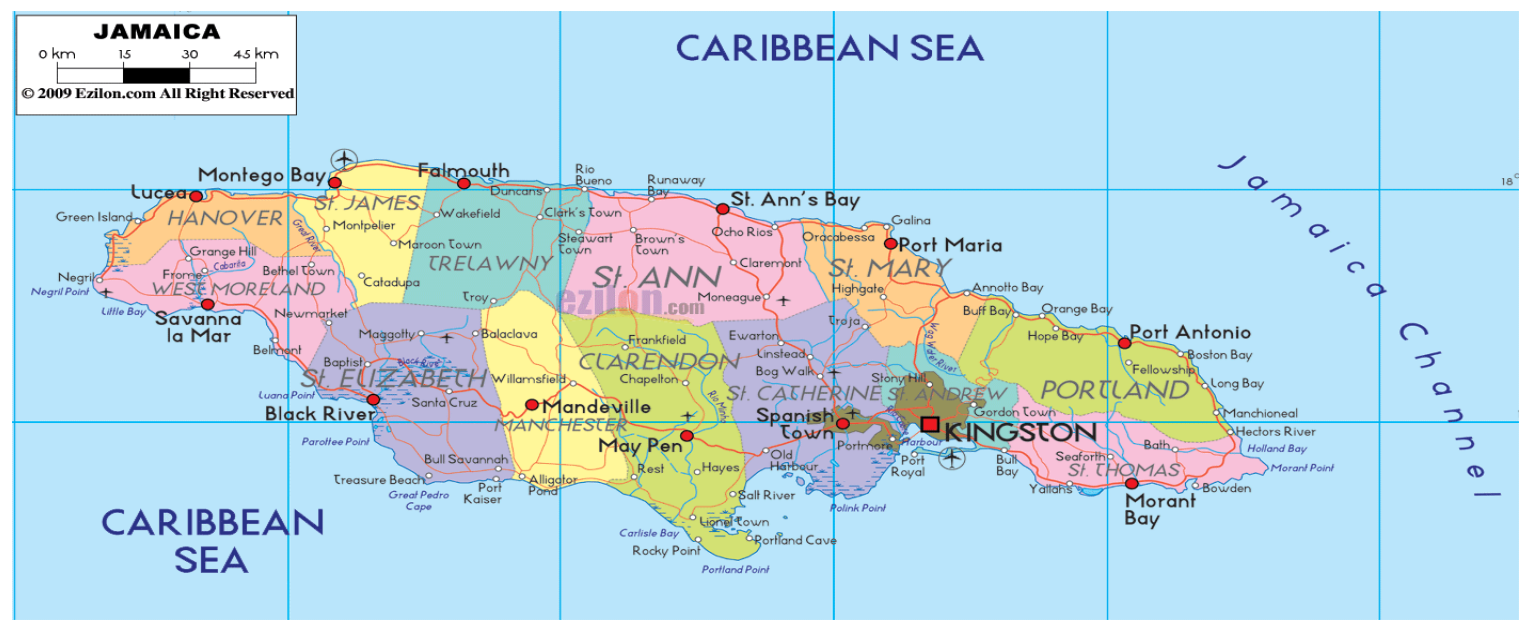

Figure 6: Map of Jamaica by Parishes.

Source: https://www.google.com.jm/search?q=map+in+jamaica\&biw

Key: Capital of each parish is marked by a red circle or red square

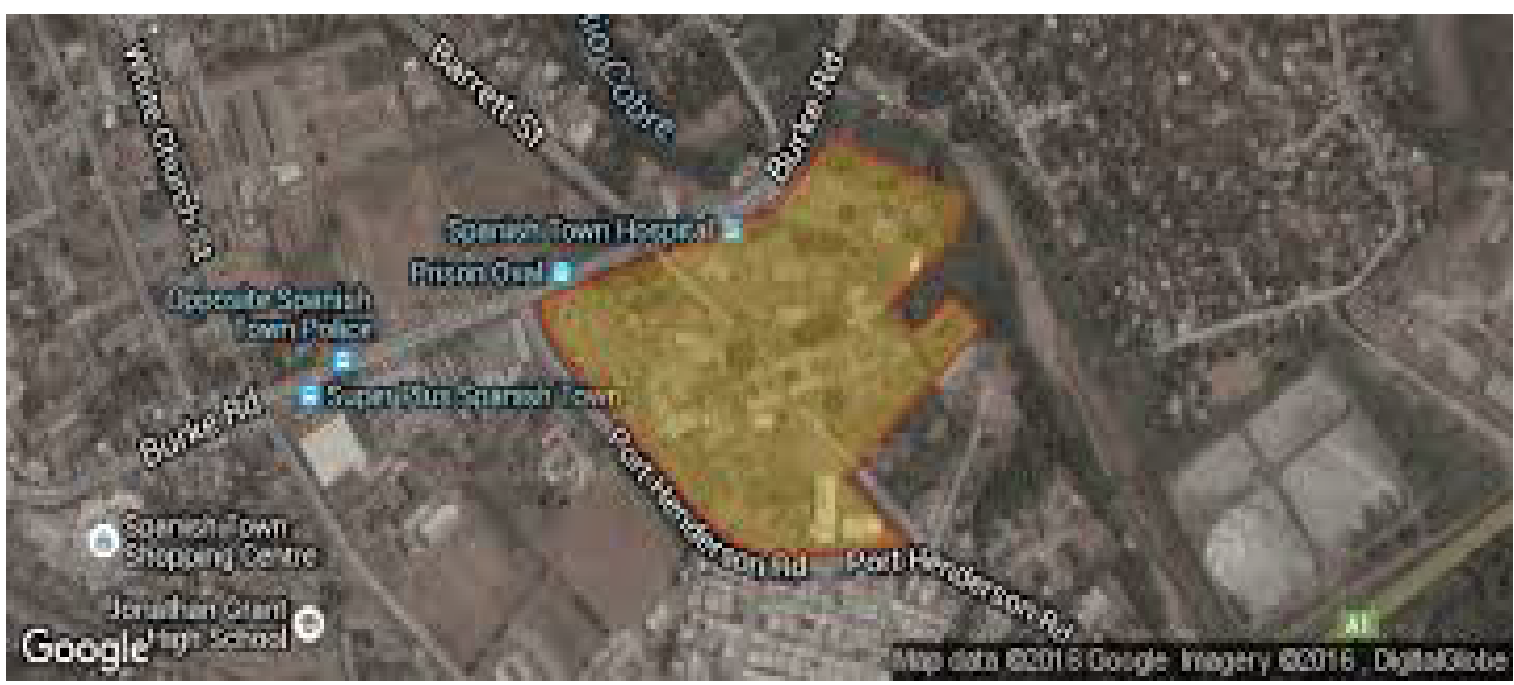

Figure 7: Map of Spanish Town and location of Spanish Town Hospital.

Source: https://www.google.com.jm/search?q=history+of+spanish+town+hospital+jamaica\&biw

one place for long". He indicated that is a low perform; "but I can do better if I could just concentrate or sit down for some time to do my school work".

"I can't go outside because of gunshots in the community. I fear outside in the community. My uncle fights his wife and a police had to discharge his firearm for him to stop and this happened at my home. It is difficult to study in my home and my community, violence. I know, I am able to do much better in school; but I am unable to revise or do assignment at home" Sian (pseudo name) said.

Paul (pseudo name) mentioned that "My grades are low because I am unable to concentrate as I am low on energy, highly confused and easily frustrate. There is too much violence in my community. I'm tired of it".

In an elite interview with the Guidance Counselor, she reported that community violence inversely affect the performance of many students. She indicated that the communi- ties close to the school are violent prone and that gunshots have been heard many times while at school. The Counselor indicated that school has been disrupted on many occasions following community violence and that school had to close on some occasions. She rated violence in the community at a moderate level and this explains why many of the pupils are poor performers in school work. The Guidance Counselor of the school has worked at the school for the past two decades and indicated that she has witnessed people being physically abused by gangsters, including seeing gangsters with guns.

\section{Discussion, Conclusions and Recommenda- tions}

\section{Introduction}

This chapter is a discussion of the literature contrasted and compared with the present findings. Herein are similarities and differences between what obtained in the literature 
and the current work. The chapter extends beyond an essay to a critical discussion as well a present of germane recommendations that are in keeping with the findings. The recommendations are primarily concerned with assisting policy makers with empirical findings so that policies and interventions can be implemented based on research findings.

\section{Violence in Jamaica}

There have been much public discussion about the state of violence in the Caribbean [85-87], with Jamaica being among nations with the most homicides in the world top $10[87,88]$. In keeping with the high rates of crimes in the region, particularly homicide, the International Bank of Reconstruction and Development (i.e., World Bank) sponsored an ethnographic study in 1996 that examined the state of crime in 5 Caribbean nations [74]. Inspite of the efforts of Caribbean scholars and the World Bank, Bourne, et al. $[85,86,89,90]$ have empirically found that homicide rates have increased exponentially since 1996. In fact, Bourne and his colleagues indicated that homicide has reached a pandemic stage in Jamaica and that it is the new health epidemic [89]. From Bourne, et al.'s study, in 1995, there were 780 homicide for the year and that this increased by $115.4 \%$ in 2009 (to 1,680 murders) [90].

In 2007, when the people of Jamaica were asked to indicate the national problems, crime was identified as the leading national concern [6]. The new homicide rate was identified by Bourne and colleagues [86] as a new health pandemic, suggesting that murders have worsen in a decade since World Bank's study. Even though Bourne and his colleagues' work as well as Powell, et al.'s research did not disaggregated the homicide cases in Jamaica [91], statistics from the Jamaica Constabulary Force identified Spanish Town as among the top crime shots in the nations [92].

Spanish Town is the capital of St. Catherine (i.e., Map below - Figure 6) and the Spanish Town Hospital is midst of the two rivaling political gangs (One Order, affiliated to the Jamaica Labour Party; Clansman, affiliated to the People's National Party), adjacent to many violent prone inner-city communities - Thompson Pen, Lakes Pen, Lauriston, Shelter Rock, St. Johns Road, De la Vega City, Lime Tree and De la Vega City - Figure 7.

Spanish Town is surrounded by many violate inner city communities (Figure 7), with sporadic violence being a staple of the area [93-100]. There are times when chaos reigns in Spanish Town [101] and law enforcement is called upon to address the issue $[94,102]$. Violence is nothing new in Spanish Town as this goes back to the 1800s. In 1836, Governor Lionel Smith declared the City of Spanish Town ruin from the attacks of 1655 by the British. The Capital of Kingston was then renamed from Spanish Town to Kingston in 1865 by Sir John Peter Grant [103-105]. The health care professionals at the Spanish Town Hospital are frequently called upon to provide health care for victims resulting from the rival communities' confrontations. In periods of violent clashes between rival political gangs and/or between criminals and police, the Spanish Town Hospital sees an increase in gun related wounds, asthma patients and knife wounds. Morgan [106] opined that the Jamaica's crime problem is bigger than the police and in such a perspective is supported by Jamaicans. When the people of Jamaica were asked to indicate the top 10 leading national problems, crime and violence emerged as the leading concern [6] and with police forwarding that Spanish Town is a crime hot spot in the nation [93], the issue of academic performance and violence among students who reside and schooled in the area must be examined.

\section{Violence in Spanish town}

Students' and guidance counselor's perspectives: Schools in Spanish Town, especially on St. John's Road, are continuously exposed to gang warfare. The students and their teachers are sometimes caught in the crossfire between gang members as well as gangsters and the police. Many of the students at studied school, located on St. John's Road, Spanish Town, St. Catherine, are residence of adjacent communities, which means that they are exposed to constant violence. The studied school is in the crime hotspot of Spanish Town $[107,108]$ and the participants gave graphic accounts of their exposed to violence including the death of parent or relative(s). Students in this research indicated that violence is relatively high rate of in their communities; with the average value for the violence index being $51.9 \pm$ $6.7,95 \% \mathrm{Cl}: 47.4-56.4$, with the maximum value being 58 and the minimum being 39. A cross-sectional research of some 1,300 fifth-graders in Jamaica revealed that $4 / 5$ of them were moderately exposed to violence [24], with this study indicating that some urban area children are even more exposed to violence than others ( $73 \%$ being highly exposed to violence).

Many of the students at studied school, located on St. John's Road, Spanish Town, St. Catherine, are residence of adjacent communities, which means that they are exposed to constant violence. The studied school is in the crime hotspot of Spanish Town $[107,108]$ and the participants gave graphic accounts of their exposed to violence including the death of parent or relative(s). This research provides new empirical findings of children less than 12 years on, their views on community violence, and how it affects their academic achievement.

The students gave detailed accounts of violent acts that they are witnessed or that have occurred in their area of residence. All the participants of the study stated that community violence range from the involvement of police officers and gang members, gang members and innocent community members, and internal as well as external gang violence. The high rates of violence that the sampled students are exposed are similar to what obtained outside of Spanish Town as well as Jamaica as well as in schools [12,109-111]. While the Guidance Counselor did not witnessed a murder, these have been witnessed by students in this research. Lionel (pseudo name) witnessed a brutal gang murder. "One day I was babysitting and saw five men, tie a rope around and throw a big stone on the man's head" Lionel said. He continued that "the man was left to die and my mother called the police. Lionel recalled a personal incident and during his recollection, he paused and then relates the occasion. "One nigh my parents were 
walking about mid-night. Somebody called my father and said someone was looking for him. Then, a man pointed a gun at him and asks who are you? The man with the gun shot at my father. My father told my mother to run. She ran and about 10 minutes after, I hear a shot. Early in the morning, I saw my grandfather body on the ground".

The gruesome of some of the violent acts are captured into this recollection by a student who is less than 12-yearsold. Michelle explained that "One day, my father was gambling on the roadside when a man in black, camp up to him and said 'wa a gwan'. He looked up. The man said, do what you have fi do and done. Then, shot him in his feet first. My father said, just finish it. Then, the man shot him in his head. I was hurt and by friend fainted. My smaller brothers and sisters will not know their father." Pottinger [112] explained that there is a psychology to exposure to violence, which explains participants in this study indicating that they cry, act out their frustration, inability to concentrate, rebellious and face the difficulty to chart a progressive path for their lives. The aggression and crime in adulthood are mere expressions of what obtains in childhood [113], because of psychology of violence on the behavioural outcome of people.

The exposure to violence among students in this study is not different from what obtains in the United States [114116]. This study is not an empirical one on the exposure of students to violence like what obtained in New Orleans [115]. Osofsky, et al. [115] found that 9/10 children 9-to-12 years old have witnessed some kind of violence in their community, which is the case in this research. Pottinger [110] outlined that many Jamaican children are exposed to violence, which is an explanation for the gruesome experienced of students in this research. This lead to the question of does exposure to community violence among a group of sampled participant affect their academic performance?

\section{Academic performance and community violence}

From the literature reviewed, violence in schools had varied and far reaching effects on students, teachers and the school system [117-119]. The incidents of violence in schools not only posed a threat to the safety of teachers, students, and teachers but also proved to be a challenge to the authority of school administrators. Many teachers have been verbally abused, physically attacked or threatened by students or their relatives [119]. If schools are to be safe there should be a lack of psychological stress and physical harm [49]. The antisocial behaviour of students endangered the safety of school personnel. Students and staff members suffered psychologically and physically because of violence in schools, which is expressed in terms of underachievement among those who are exposed to violence [24]. Baker-Henningham, Meeks-Gardner, Chang, and Walker's study [24] revealed that fifth-graders are more exposed to violence have a lower academic performance compared to those who are lesser exposed to violence and this offers some insights to the poor performance of students in this paper. For this research $89 \%$ of the sampled participants indicated that their academic performance is influenced by exposure to community violence, which accounts for the academic achievement gap identified in the literature $[120,121]$ and explains the general poor performance of students at the studied school.

In Jamaica there is academic achievement gap among urban area students, example between the studied school and those in urban area middle-to-upper class neighbourhoods, and this is clarified by the works of Basch [120] and Contreras, Elacqua, Martinez, and Miranda, [121] that it is the exposure to violence that accounts for the disparity in achievement. In this research, both the Guidance Counselor and the participants indicated that exposure to community violence inverse affects academic achievement of students, which is explained from a trauma perspective by Strom, Schultz, Wentzel-Larsen and Dyb [122]. Using a longitudinal study of 64 students who have completed three years at senior high school, Strom, et al. [122] found that grades declined one year after being exposure to trauma and that their graders improved two years after the incident. It is easy, therefore, to comprehend the rationale for the continued poor performance of students in this study as they are continuously exposed to community violence and this is retard future academic achievement. Another study by Strøm, et al. [122] revealed that students who were bullied showed a 0.98 point decline in grades following each unit of increment in being gullied at school, which must be worst for exposure to violence, especially to the murder of a parent as is the case for participants in this study (see also, Patterson Silver Wolf, et al. [123]).

Maguire, Williams, Naughton, Cowley, et al. [124] offered a different perspective on issue of violence and academic performance by opining that lower intelligence, reduced literacy and numeracy were observed among students who experienced long-term emotional abuse and neglect. Such theorizing holds another key to the performance gap among school-based children whom have been exposed to long-term community violence. While the Guidance Counselor indicated the high level of antisocial behaviour, it may to extending too far a perspective that students are of a lower intelligence simply because of lower grades or the performance gap between those who are exposed to violence and those who are not. There can be no denial about the long-term effects of abuse on the psychological as well as physical ability of people, including children, Norman, Byambaa, De, Butchart, et al. [125] argued that more research are need to establish the relationship between chronic disease, lifestyle risk factors and maltreatment, which means that caution should be taken in ascribing intelligence disparity for the studied participants.

\section{Exposure to violence and anti-social behaviour of students}

At school: The influence of the community is a causal factor of violence by norms and values. Devine further stated that teachers adopting a 'hands off' response to violence and concentrating only on their role in the classroom have led to the escalation of violence. The easy access to news and information through the Internet and other electronic media regarding the use of weapons is cause for concern as students adopt several types of deviant behaviour and act them out in school. Students are exposed 
to violence in the media, which can result in acceptance and emulation of aggression. Ascher [21] and Widom [126] believed that exposure to violence causes one to commit acts of violence. Felner and Felner [127] stated that family variables, individual characteristics and societal factors affect violence. Family variables include economic status, divorce, abuse as well as unskilled parenting. Individual characteristics include antisocial behaviour, psychological disorder and personality. Societal factors include access to weapons, media violence, community violence, or influence, as well as inequitable educational opportunities. Norguera, [59] stated that teachers' and administrators' unfamiliarity with the environment from which students come, contributed to unfounded stereotyping of students. This affects a positive interaction between students and teachers evidenced if the student is from violence prone areas or inner city communities. There is a relatively high occurrence of physical violence in schools. The incidents of violence discourage many Jamaican students from attending school, which is likely to impair the learning ability and school performance of students who are victims [12].

While the significant correlation between exposure to antisocial behaviour and expressed antisocial behaviour of the people is well documented in the literature, Blinn-Pike, Berger, Dixon, et al. [128] cautioned against ascribing to the issues causality because of the conflictory findings that have emerged in recent studies. Such offers can account for obtains in the present work as not all the participants exhibit the same antisocial behaviours. Some of the participants were less defiant, more cooperative and less disrespectful to teachers including become engaged into physical confrontations as some show behaviours such as sleeping in class, less class participation and failure to complete home assignments for class. The latter reason is explained by the Guidance Counselor that the pupils' inability or failure to complete homework for their teachers are tied to the state and nature of violence and the response of the family while at home. The issue is, sometimes when violence begins in the community, students are forced to hide under the bed, on the floor, turn off lights and this explains why they not be able to complete assignments, review materials taught in schools and even retain some of the things taught by the teacher the previous days, weeks or months.

It is a fact that there is a significant correlation among the micro-systems in a society [35] and short term-to-long term effects of the social psychology abuse and behaviour $[32,37-39,41]$, there should be not surprise as to the why participants in this research are hyperactive, reckless, exhibit deviant behaviour, inability to concentrate for extended periods, poor social skills, because they are the products of their socialization [14,45] and Cole [46] explains the frequency of the social deviance comes across as the norm to the children than otherwise.

In order to understand what Cole [46] is explaining about the normalcy of social deviance and students' practice of these behaviours, a presentation of the exposure to violence and the typology of the acts should be forwarded here. The majority of the participants have witnessed a murder $(72.7 \%$, $\mathrm{n}=8$ ) and shootings $(45.5 z \%, \mathrm{n}=5)$, with a few having witnessed a rape $(36.4 \%, n=4)$. All the participants indicated that the witnessed violence in their community has adversely affected their behaviour. A participants indicated that "You must defend yourself in my community, because you will be considered as soft and preyed upon", which speaks to Cole's perspective about the significant correlation between exposure and practiced behaviour. The issue embedded in the what is unfolding among the participants in this study is the socialization process, which Skiba and Peterson [47] opined account for the influence of the school and community on patterns of aggressive and violent behavior among students. This research found that $73 \%$ of the participants were engaged into a physical conflict, which is just an explanation of the literature of the sociology of culture [129] to include the image forwarded by the media $[130,131]$. Thus, there can be no denial; therefore, that the socialization process is Jamaica is influence later the development of adults because of earlier exposure to social deviance [55].

\section{Strategies}

With the reality that socialization plays a critical role in practiced behaviour of children as well as adults, the state of violence in Jamaica $[85,86,89,90,132]$ explains what obtains in schools $[8,12,20,110,117]$. The state of violence in the community as well as schools atypical to Jamaica as it is global problem experienced by even developed nations like America $[118,120]$. With the context that the teaching-learning process is best done in safe and conducive environment for learning because the nature of how people learning [132149], strategies must be implement to address violence as well as deviant in school to include the bullying phenomenon.

Stanley, Juhnke and Purkey [67] opined that programmes to address violence without addressing school culture, academic achievement and existing student, parent and faculty concerns will not be effective ones. Casella [150] purported the use of a zero tolerance policy in schools, which clearly is not effective as the nature of violence as escalated with the state of violence in the general society. However, Skiba and Peterson [56] outlined the many strategies, which were being implemented to help with the prevention or decline of antisocial or violent behaviour. Mulvey and Cauffman [57] tried to alleviate the fear of parent(s) and/or guardian(s) that despite the violence which occurred in schools, these institutions had proven to be one of the safest places for youths, which could explain why many parents and/or guardians continue to send their children/wards to schools in places like Spanish Town, St. Catherine, Jamaica.

For the present study, the Guidance Counselor indicated that cannot take a zero tolerance approach because of the psychological trauma that many of the students of been exposed, which is anti to the zero tolerance approach forwarded by some in the literature [66]. It is easy to comprehend, therefore, why institution to which the Counselor is employed uses other strategies as against zero tolerance and a part of the rationale is embedded in what Kang-Brown, Trone, Fratello, and Daftary-Kapur [151] opined the "The culture of disci- 
pline in educational settings has changed profoundly over the past 25 years" (p. 1). Hence, the aforementioned justification is premise upon which studied institution have chosen to use music, storytelling, games, drama, research, role playing and counseling. The Guidance Counselor as the studied school suggested that while some antisocial behaviour emerged on a regular basis, the occurrence would have been more and a likeliness of other things being done if those strategies have been used. Drama and role playing along with storytelling are some of the strategies that have been employed by the guidance department and positive benefits have been observed. The students who exhibit social deviant acts when placed through the various strategies become less boisterous, rebellious and disrespecting of their peers as well as their teachers. Even among the new converts, there have been outburst, deviant acts and disrespectful tendencies; but the occurrences are usually lower than when nothing was done. She said that "The teachers have reported changes in some of the students and while they indicated no change in other, we have been making significant strides in behaviour modifications of psychological challenged students", which supports the literature on the diverse approaches to address social deviance in schools with less enforcement of zero tolerance [151].

Smith and Sandhu [64] reported that most policies were seen as punitive rather than edifying. Most of the approaches were problem focussed in that they targeted negative behaviour as opposed to building alternative prosocial skills, which explains why the Guidance Counselor in this study avaided the widespread usage of zero tolerance approach because the school is a teaching-learning environment, especially because of cultured normalcy of many of the students therein. Kang-Brown, Trone, Fratello, and Daftary-Kapur [151] provided empirical evidence that Researchers also looked for potential indirect effects, examining whether the school climate might influence students' peers, family circumstances, and overall communities in ways that led to greater involvement with the justice system. They found no evidence that attending a school with zero tolerance policies either deters delinquency or places youth at a higher likelihood of becoming justice system-involved, in the short- or long-term (p. 8)

Kang-Brown, et al.'s work, therefore, is a critical justification in support of Guidance Counselor's low usage of zero tolerance strategies in seeking to curb social deviance among of group of pupils whom have been cultured in a milieu of violence. The thought of zero tolerance approaches to every type of violent act in and of itself is unfair as the same treatment could not be meted out to every problem [66] were critical of the zero- tolerance policy. A denial of one's education for relatively minor reasons was viewed as a violation of one's rights in a democratic society and this could make schools in Jamaica prime targets by thugs. Hence, low usage of zero tolerance by the studied school may hold some of the keys to infrequent gang violence occurring on the compound among viral gangs that are adjacent to the school.

When a pupil at most 11-years-old, who expresses social deviant acts at school, reported how community violence caused a physiological act, it is difficult to understand how zero tolerance can be used to address the expressed behavioural problems. The male-participant said "whenever I hear gunshots, I pee himself." I am unable to concentrate at school, I am day-dreaming about violence in my community, I feel weak and do not know why I can't stay one place for long." He continued that "but I can do better if I could just concentrate or sit down for some time to do my school work" and so the approaches employed by the school alleviates some of the frustrations as against allowing him to internalize the act of the school as 'unfair' and one day make the matter more detrimental for the institution as well as its teachers.

National Association of Social Workers [61] found that students who gained knowledge and skills in resolving conflicts were able to apply the skills to conflict situation, which is the clearly explaining the choiced strategies employed by the studied institution. The zero tolerance strategies would have immediately address the social deviance of the students; but Flannery [63] reported that some methods undertaken were short, "quick fix" methods or sophisticated multifaceted long term programs. Ascher [21] was critical of the methods being used and referred to the schools as "fortresses", which offers some insights to justifications of the low usage of zero tolerance strategies at the studied schools. If the school was to employ the 'quick fix' of zero tolerance, then it would be in keeping with what Ascher [21] described as schools were more of a garrison type in which not many teachers felt at ease despite the concerns for safety.

\section{Conclusion}

A school with a robust process in place that routinely monitors students' behavior, consistently enforce the school's policies and regularly communicate the expectations to staff, students and parents can dramatically improve the quality of their school climate. Furthermore, administrators share a vital role in ensuring that the school climate is secured and work to promote an environment for students to learn and develop to their full potential. Therefore, efforts should be made to identify those behaviors such as bullying and community violence could impact academic achievement and the well-being of students. This study clearly shows how urban community violence is creating a performance gap among children and that policies and programmes must be implemented to address this academic gap deficit created by the social climate. The children are exposure to gruesome psychological stress and many of their behaviours are indicators of post-traumatic stress disorder.

\section{Recommendations}

\section{Policy}

The findings that germinate from this study provide the bedrock for the recommendations herein. The researcher recommends a Safe School Climate Coordinator in implementing programs and policies to improve the safety of their schools in addition to reducing social deviance. Coordinators that promote a safe learning environment helps to build a school community that is free of social de- 
viance activities, which is vital in mitigating the cultured behaviour among students.

Secondly, the researcher is proposing that a Manual be developed to aid teachers in the identification of behaviours caused by the cultured environment and how to address some of these activities. Thus, this could be a supplement to the Parent-Student Handbook. The Parent-Student Handout will offer training to families on a yearly basis and includes explicit distinguishing details about social deviant activities including bullying, teasing and harassment and other violent acts in the community and how they influence a pupil's academic performance. The Handbook will outline how to identify social deviant acts, restorative institutions to aid in behaviour modifications as well $s$ their contact information.

The Ministry of Education should make available to all schools in violent prone areas psychiatrists, psychologists and grievance counselor. Those practitioners will add identified pupils to deal with the violence in their community and how best to cope with the situations as well as avenues of alleviation expressions.

Boyd [152] claimed that involving stakeholders such as students, parents and teachers can highlight areas of concern that might not otherwise be evident through robust policies and monitoring of students' behavior. The differences between the students and teacher's perception of school climate can be presented through the survey results. The sharing of relevant information can serve as the basis for policy changes or policy development [151]. The frequency of these surveys is based on the schools' resources. Subsequent surveys can be administered based on the outcome and the data presented.

\section{School-based survey}

NSCC $[153,154]$ claimed that data collected through climate surveys is useful in improving student achievement and contributes to the positive development of adolescents. The newly enacted legislation requires that school climate surveys be done. The purpose is to help schools undertake this activity. Sample surveys are available for teachers, students, and parents that can be used as is or adapted [155].

\section{Media}

The government news to use to media to provide safe school, safe communities and educate people on symptoms of stressors that are likely to negatively impacts the psychological state of students and where they can go for assistance.

\section{References}

1. Chuck Delroy (1986) Understanding crime: An introduction. Caribbean Law Publishers Inc, Brigdetown, Barbados.

2. Harriott A (2000) Police and crime control in Jamaica: Problems of reforming ex-colonial constabularies. University of the West Indies Press, Kingston, Jamaica.

3. Harriott A (2003) Fear and criminal victimization in a reputed violent environment. Social and Economic Studies 52: 35-72.

4. Harriott A (2004) Introduction. In: Harriott A, Brathwaite F,
Wortley S, Crime and criminal justice in the Caribbean. (edn), Arawak Publication, Kingston.

5. Ellis H (1991) Identifying crime correlates in a developing society: A study of socio-economic and socio-demographic contributions to crime in Jamaica 1956-1984. Peter Lang Publishers.

6. Powell LA, Bourne P, Waller L (2007) Probing Jamaica's political culture. Centre for Leadership and Governance 1.

7. March C, Bourne PA (2011) The influence of macroeconomic factors on murders in Jamaica: Should the police be cautious in interpreting the murder statistics? Asian Journal of Business Management 3: 257-277.

8. Bourne PA, Hudson-Davis A, Sharpe-Pryce C, et al. (2015) The psychology of homicide, divorce and issues in marriages: Mental health and family life matters. International Journal of Emergency Mental Health and Human Resilience 17: 389-405.

9. Bourne PA (2012) Murder and ill-health: A health crime phenomenon. J Behav Health 1: 138-146.

10. Bourne PA, Solan I (2012) Health, violent crimes, murder and inflation: Public health phenomena. J Behav Health 1: 59-65.

11. Bourne PA, Pinnock C, Blake DK (2012) The influence of violent crimes on health in Jamaica: A spurious correlation and an alternative paradigm. Journal of Clinical and Diagnostic Research 6: 5-12.

12. Soyibo K, MG Lee (2000) Domestic and school violence among high school students in Jamaica. West Indian Medical Journal 49: 232-236.

13. Stuart W Twemlow (2004) Preventing violence in schools. Psychiatric times 4: 61 .

14. McEvoy A, R Walker (2000) Antisocal behaviour, academic failure and school climate: A critical review. Journal of Emotional and Behavioural Disorders 8: 130-140.

15. Bastian LD, BM Taylor (1991) School Crime: A national crime victimization survey report. Bureau of Justice Statistics, Washington.

16. Batche GM, HM Knoff (1994) Bullies and their victims: Understanding a pervasive problem in the schools. School Psychology Review 23: 165-174.

17. Lawton Douglas A (2008) Caribbean crime and violence: Using jamaica as a case.

18. LFernald LC, Meeks-Gardner J (2003) Jamaican children's reports of violence at school and home. Social and Economic Studies 52: 121-140.

19. Pottinger AM (2012) Children's exposure to violence in Jamaica: Over a decade of research and interventions. West Indian Med J 61: 369-371.

20. Samms-Vaughan, Maureen (2005) Profiles, the Jamaican preschool child: The status of early development in Jamaica. The Planning Institute of Jamaica 163.

21. Ascher C (1994) Gaining control of violence in the Schools: A view from the field. New York: Teachers College, Erick Clearinghouse on Urban Education and National Education Association, Washington, DC, USA.

22. Biovin M, Hymel S, Hodges E (2001) Toward a process view of peer rejection and harassment. In: Juvoner J, Graham S, Peer Harassment in school the plight of the vulnerable and victimized, Guilford Press, New York, 265-289. 
23. Gumpel TP, Meadan H (2000) Childrens perceptions of schoolbased violence. British Journal of Educational Psychology 70: 391-404.

24. Baker-Henningham H, Meeks-Gardner J, Chang S, et al. (2009) Experiences of violence and deficits in academic achievement among urban primary school children in Jamaica. Child Abuse Negl 33: 296-306.

25. Creswell JW (2012) Educational research: Planning, conducting and evaluating quantitative and qualitative research. ( $4^{\text {th }}$ edn), Pearson, Boston.

26. Crotty M (2005) The foundations of social research: Meaning and perspective in the research process. SAGE, London.

27. Silverman D (2005) Interpreting qualitative data: Methods for analysing talk, text and interaction. ( $2^{\text {nd }}$ edn), SAGE, London.

28. Harriott A (2003) Understanding Crime in Jamaica. University of the West Indies Press, Kingston, Jamaica.

29. Gay LR, Arasian P, Geoffrey E Mills (2003) Educational research competencies for analysis and applications. Upper Saddle River. Merill \& Pretence Hall, New Jersey.

30. D'Andrea M (2004) Comprehensive school-base violence prevention training: A developmental- ecological training model. Journal of Counselling \& Development 82: 277-278.

31. Guerrero R (2004) Collective Efficacy \& Youyh Violence. The Sir Kenneth Standard Distinguished Lecture presented at the opening ceremony of the Faculty of Medical Sciences' 13th Annual Research Conference \& workshop on Violence \& Violence Prevention. University of the West Indies Jamaica.

32. Wiehe R Vernon (1998) Understanding Family Violence, Treating and Preventing Partner, Children, Siblings and Elder Abuse. Sage Publications, Inc, London.

33. Patterson Charlotte J (2008) Child Development. Mc Graw-Hill: Boston.

34. https://medicine.yale.edu/childstudy/communitypartnerships/ cvtc/

35. Santrock W John (2008) Psychology. (11 ${ }^{\text {th }}$ edn), Mc Graw Hill: Boston.

36. Tolan Patrick, Gorman-Smith, Henry David (2006) Institute for Juvenile Research. University of Illinois at Chicago, USA, 57: 557 583.

37. Wilson KJ (2005) A Comprehensive Guide to Understanding and Ending Domestic Abuse. Hunter House Publishers Press, Salt Lake City.

38. Thompson Theodore, Massat Carol, Rippey (2005) Child and Adolescence Social Work Journal 22: 5.

39. Berkowitz Stephen J (2003) Children Exposed to Community Violence: The Rationale for Early Intervention Journal: Clinical Child and Family Psychology Review 6: 293-302.

40. Chevannes, Barry (1996) They Cry "Respect" Urban Violence and Poverty in Jamaica: Mona: Jamaica.

41. Bronte-Tinkew, Jacinta MH (2000) A thesis in sociology and Demography. Bell and Howell Information \& Learning Company: Ann Arbor. MI.

42. Samms-Vaughan ME, Jackson MA, Ashley DE (2005) Urban Jamaican children's exposure to community violence. West Indian med J 54: 14-21.
43. Bandura A (1977) Social learning theory. Prentice Hall, Englewood Cliffs, New Jersey.

44. Hawkins JD, RR Catalano (1992) Violence in American Schools: A New perspective. Elliott DS, Williams KR, Hamburg BA, Cambridge University Press, England.

45. Leone Peter E, Mayer Matthew J, Malmgren Kimber, et al. (2000) School violence and disruption: Rhetoric, reality, and reasonable balance. Focus on Exceptional Children 33: 1-20.

46. Cole TB (1995) Targeting guns: Firearms and their control.

47. Skiba RJ, RL Peterson (2000) The school shooter. A threat assessment perspective. Federal Bureau of Investigation, Quantico, VA.

48. Steinberg L (2000) Youth violence: Do parents and families make a difference? National Institute of Justice Journal.

49. Nelson JR, RM Marchand, N Marchand-Martella (2004) Handbook of research in emotional and behavioural disorders. Guilford Press, New York, NY.

50. Santrock JW (2001) Adolescence. 8TH edition, Mcgraw-Hill, New York.

51. Robert Diguilio (2001) Educate, mediate, or Litigate? What teachers, parents, and administrators must do about student behaviour. Publisher Corwin Press, California.

52. Olweus D (1993) Bullying as school: What we know and what we can do. Wiley.

53. Dodge K, JE Bates, G Pettet (1990) Mechanisms in the cycle of violence. Science 250: 1678-1683.

54. Sives A (1997) Violence and Politics in Jamaica. Unpublished doctoral dissertation, University of Bradford, Bradford.

55. Osofsky JP (1999) The impact of violence on children. Future Child 9: 33-49.

56. Skiba RJ, RL Peterson (1999) The dark side of zero-tolerance: Can punishment lead to safe schools. Phi Delta Kappan 80: 372-382.

57. Mulvey EP, Cauffman E (2001) The inherent limits of predicting school violence. American Psychologist 56: 797-802.

58. Lantieri I, Patti J (1999) Waging peace in our schools. Beacon press, Boston Mass, United States.

59. Norguera P (1995) Reducing and preventing violence: An analysis of causes and an assessment of successful programs. Harvard Education Review, California.

60. Baker-Henninghan H, Meeks-Gardener J, Chang-Lopez S (2007) Experiences of violence and academic achievement deficits among urban primary school children in Jamaica. 52nd Scientific Meeting Caribbean Health Research Council Conference, Montego Bay, Jamaica.

61. Skiba RJ, RL Peterson (2001) Best practices in violence prevention and intervention. National Summer Institute for Social Workers, Nashville, USA.

62. Mayer M, P Leone (1999) A structural analysis of school violence and disruption: Implications for creating safer schools. Education and Treatment of Children 22: 333-356.

63. Flannery DJ (1997) School violence: Risk preventive intervention and policy (Urban diversity series, 109). Case Western University, Cleveland, Ohio, USA.

64. Smith DC, DS Sandhu (2004) Toward a positive perspective on violence in the schools: Building Connections. Journal of Counseling \& Development 82: 287-293. 
65. Glasser W (2000) School violence from the perspective of William Glasser. Professional School Counseling 4: 77-80.

66. Curwin RL, AN Mendler (1999) Zero tolerance for zero tolerance. Phi Delta Kappan 78: 119-120.

67. Stanley PH, GA Juhnke, WN Purkey (2004) Using an invitational theory and practice to create safe and successful schools. Journal of Counseling \& Development 82: 302-309.

68. Casella R (2003) Zero tolerance policy in schools: Rationale consequences, and alternatives. Teachers College Record 105: 872892.

69. Neuman WL (2006) Social research methods: Qualitative and quantitative approaches. ( $6^{\text {th }}$ edn), Pearson/Allyn and Bacon, New York, USA.

70. Kuhn T (1996) The Structure of scientific revolutions. (3 $3^{\text {rd }}$ edn), The University of Chicago Press, USA.

71. Berg B (2001) Qualitative Research Methods for the social sciences. ( $4^{\text {th }}$ edn), Allyn and Beacon, USA.

72. Burnard $P$ (2004) Writing a qualitative research report. Nurse Educ Today, 24: 174-179.

73. Babbie $E$ (2007) The practice of social research. (10 $10^{\text {th }}$ edn), Wadsworth, a Division of Thomson Learning, Inc.

74. Levy $\mathrm{H}$ (1996) They cry 'respect'!: Urban violence and poverty in Jamaica. Centre for Population, Community and Social Change, University of the West Indies, Mona, Kingston, Jamaica.

75. Sevignty M (1978) A descriptive study of instructional interaction and performance appraisal in a university studio art setting: A multiple perspective. Doctorial dissertation, Ohio State University, 38: 6477

76. Johnson DW, Johnson RT, Dudley B (1992) Effects of peer mediation training on elementary school students. Mediation Quarterly 10: 89-99.

77. Creswell JW (2013) Research Design: Qualitative and quantitative and mixed-method approaches. SAGE Publications, Thousand Oaks, USA.

78. Strauss A, Corbin J (1998) Basics of qualitative research: Techniques and procedures for developing grounded theory. $\left(2^{\text {nd }}\right.$ edn), SAGE, Newbury Park, CA, USA.

79. Dainty ARJ, Bagilhole BM, Neale RH (1997) Analytical strategies for dealing with qualitative data in construction management research. Construction Management 2: 484-493.

80. Saldana J (2009) The coding manual for qualitative researchers. SAGE Publication, London.

81. Weber M (1949) The methodology of the social sciences, trans. In: Shils E, Finch H, Free Press, New York.

82. Weber M (1974) Subjectivity and determinism. In: Giddens A Positivism and sociology, Heinemann, London, 23-32.

83. Weber M (1981) Some categories of interpretative sociology. The Sociological Quarterly 22: 151-180.

84. Miles MB, Huberman AM (1994) Qualitative data analysis: An expanded sourcebook. ( $2^{\text {nd }}$ edn), Sage Publications, Thousand Oaks, CA, 40-43.

85. Bourne PA, Hudson-Davis A, Sharpe-Pryce C, et al. (2015) Homicide, rape and carnal abuse in Jamaica, 1970-2013: The New Health Pandemics. International Journal of Emergency Mental Health and Human Resilience 17: 588-597.
86. Bourne PA, Hudson-Davis A, Sharpe-Pryce C, et al. (2015) The effects of homicides and economics on human and social biology: A mental health challenge for a society? International Journal of Emergency Mental Health and Human Resilience 17: 495-501.

87. Bourne PA (2010) Crime, tourism and trust in a developing country. Current Research Journal of Social Sciences 2: 69-83.

88. Kirk A (2015) Mapped: Which countries have the highest murder rates?

89. Bourne PA, Hudson-Davis A, Sharpe-Pryce C, et al. (2015c) Homicide, rape and carnal abuse in Jamaica, 1970-2013: The new health pandemics. International Journal of Emergency Mental Health and Human Resilience 17: 588-597.

90. Bourne PA, Hudson-Davis A, Sharpe-Pryce C, et al. (2015d) The use of sexual assaults as a weapon in marriage and legal separation: Male crisis theory. World Journal of Pharmacy and Pharmaceutical Sciences 4: 1589-1615.

91. Bourne PA, Hudson-Davis A, Sharpe-Pryce C, et al. (2014) Does marriage explain murders in a society? In what way is divorce a public health concern? Int J Emerg Ment Health 16: 84-92.

92. Jamaica Constabulary Force (JCF) (2010-2015) Statistics on violence crimes. JCF, Kingston.

93. Jamaica Gleaner (2016a) JCF increases efforts to dismantle spanish town gangs. Kingston.

94. Jamaica Gleaner (2016b) Police monitoring Spanish town as tension brews among gangs. Kingston.

95. (2009) The ghetto in spanish town, Jamaica.

96. Jamaica Observer (2013) Police take back spanish town, murders down, gangs in retreat: Residents happy, want police to stay in spanish town communities. Kingston.

97. Love Jamaica (2015) Gang wars intensify in spanish town, "Donkey" killed.

98. Robinson C (2010) Pastor among 2 killed in Spanish Town gang feud. Kingston: Jamaica Observer.

99. Robinson C (2010) Two dead in Spanish Town gang war. Kingston: Jamaica Observer.

100. Turner R, McLeod D (2016) Thugs battle for gang control: Six killed in internal conflict. Kingston: Jamaica Star.

101. Places and spaces magazine (2014) Spanish Town: From Capital City to Near Chaos.

102. Robinson C (2010) Another deadly gang forms in Spanish Town: Police concerned about emergence of 'No Order' group. Kingston: Jamaica Observer.

103. Black C (1960) Spanish Town-The Old Capital. Spanish Town: Parish Council of St. Catherine.

104. Buisseret D (1996) Historic Jamaica from the air. Kingston: Ian Randle Publishers.

105. Sherlock P, Campbell H (1998) The Story of the Jamaican People. Kingston: Ian Randle Publishers.

106. Morgan DL (1998) Practical strategies for combining qualitative and quantitative methods: Applications to health research. Qual Health Res 8: 362-376.

107. Jamaica Observer (2015) Bullet-riddled body found in car St. John's road.

108. RJR (2011) Police identify St. John's road murder victim. 
109. Arciaga M, Sakamoto W, Jones EF (2010) Responding to gangs in the school setting. National Gang Center Bulletin 5: 1-15.

110. Pottinger AM (2012) Children's exposure to violence in Jamaica: Over a decade of research and interventions. West Indian Med J 61: 369-371.

111. Stanley N, Ellis J, Farrelly N, et al. (2015) Preventing domestic abuse for children and young people: A review of school-based interventions. Child Youth Serv Rev 59: 120-131.

112. Pottinger AM (2009) Psychological outcomes associated with exposure to violence co-occurring in multiple settings for Jamaican children: home, school and community. Caribbean Childhoods: Journal of the Children's Issues Coalition 4: 93-111.

113. Samms-Vaughan ME, Jackson MA, Ashley DE (2005) Urban Jamaican children's exposure to community violence. West Indian Med J 54: 14-21.

114. Ratner HH, Chiodo L, Covington C, et al. (2006) Violence exposure, IQ, academic performance, and children's perception of safety: Evidence of protective effects. Merrill-Palmer Quarterly: Journal of Developmental Psychology 52: 264-287.

115. Osofsky JD, Wewers S, Hann DM, et al. (1993) Chronic community violence: What is happening to our children? Psychiatry: Interpersonal and Biological Processes Special Issue. Children and violence 56: 36-45.

116. Milam AJ, Furr-Holden CDM, Leaf PJ (2010) Perceived school and neighborhood safety, neighborhood violence and academic achievement in urban school children. Urban Rev 42: 458467.

117. Riddell A, Bailey D, Valentine N (2013) Questioning school violence in Jamaican Schools: A critical perspective. Caribbean Partners for Educational Progress. EduExchange E-Discussion Summary.

118. Centers for Disease Control (CDC) (2016) Understanding school violence.

119. Sives A (2003) The historical roots of violence in Jamaica: The Hearne Report 1949. In: A Harriott, University of the West Indies Press, Kingston, 49-62.

120. Basch CE (2011) Aggression and violence and the achievement gap among urban minority youth. J Sch Health 81: 619-625.

121. Contreras D, Elacqua G, Martinez M, et al. (2015) Income inequality or performance gap? A multilevel study of school violence in 52 countries. J Adolesc Health 57: 545-552.

122. Strøm IF, Schultz JH, Wentzel-Larsen T, et al. (2016) School performance after experiencing trauma: A longitudinal study of school functioning in survivors of the Utoya shootings in 2011. Eur J Psychotraumatol 7.

123. Patterson Silver Wolf DA, Perkins J, Van Zile-Tamsen C, et al. (2016) Impact of violence and relationship abuse on grades of American Indian/Alaska Native Undergraduate college students. J Interpers Violence 33: 3686-3704.

124. Maguire SA, Williams B, Naughton AM, et al. (2015) A systematic review of the emotional, behavioural and cognitive features exhibited by school-aged children experience neglect or emotional abuse. Child Care Health Dev 41: 641-653.

125. Norman RE, Byambaa M, De R, et al. (2012) The long-term health consequences of child physical abuse, emotional abuse, and neglect: A systematic review and meta-analysis. PLoS Med 9.

126. Widom CS (1991) The role of placement experience in mediating the criminal consequence of early childhood victimization.
Am J Orthopsychiatry 61: 195-209.

127. Felner RD, TY Felner (1989) Primary prevention programs in the educational context: A transcational ecological framework analysis. In: LA Bond, BE Compas, Primary prevention and promotion in schools. Sage Publications, Newberry Park, 255-296.

128. Blinn-Pike L, Berger T, Dixon D, et al. (2002) Is there a causal link between maltreatment and adolescent pregnancy? A literature review. Perspect Sex Reprod Health 4: 68-75.

129. Sharma B, Nam EW, Kim HY, et al. (2016) The influence of witnessing inter-parental violence and bullying victimization in involvement in fighting among adolescents: Evidence form a school-based cross-sectional survey in Peru. J Lifestyle Med 6: 27-35.

130. Bushman BJ (2016) Violent media and hostile appraisals: A meta-analytic review. Aggress Behav 42: 605-613.

131. McGinty EE, Wolfson JA, Sell TK, et al. (2016) Common sense or gun control: Political communication and new media framing of firearm sale background checks after Newton. J Heatlh Polit Policy Law 41: 3-40.

132. Lemard G, Hemenway D (2006) Violence in Jamaica: An analysis of homicide 1998-2002. Inj Prev 12: 15-18.

133. Alonso AA (2007) Creating and sustaining environments to support teaching and learning. Baltimore City Public School System's Comprehensive School Safety Plan.

134. (2000) How people learn: Brain, mind, experience, and school. In: Bransford J, Brown A, Cocking R, National Academy Press [National Research Council]. Washington DC.

135. (2009) Learning and teaching early math: The learning trajectories approach. In: Clements DH, Sarama J, Routledge, New York.

136. Crick RD, McCombs B, Haddon A (2007) The ecology of learning: Factors contributing to learner-centred classroom cultures. Research Papers in Education 22: 267-307.

137. Cross D (2009) Creating optimal mathematics learning environments: Combining argumentation and writing to enhance achievement. International Journal of Science \& Mathematics Education 27: 905-930.

138. Fosnot CT (2005) Constructivism revisited: Implications and reflections. The Constructivist 16.

139. Fraser S (2012) Authentic childhood: Exploring Reggio Emilia in the classroom. Nelson Education, Toronto, ON

140. Fraser BJ (1994) Research on classroom and school climate. In: DL Gabel, Handbook of research on science teaching and learning, Macmillan, New York, 493-541.

141. Harris Helm J, Beneke S, Steinheimer K (2007) Windows on learning: Documenting young children's work. Teachers College Press, University of Michigan, MI.

142. Hattie J (2012) Visible learning for teachers. Routledge, New York, NY.

143. Portland ME, Stenhouse Kilpatrick J, Swafford J, et al. (2001) Adding it up: Helping children learn mathematics. National Academy Press [National Research Council], Washington, DC.

144. Luke A, Freebody P (1999) Further notes on the four resources model. Reading Online.

145. OECD (2012) PISA 2012 Mathematics Framework. OECD Publications, Paris. 
146. Ontario Ministry of Education (2005) The Ontario Curriculum, Grades 1-8, Mathematics (revised). Queen's Printer for Ontario, Toronto.

147. Ontario Ministry of Education (2006) The Ontario curriculum, Grades 1-8: Language. Queen's Printer for Ontario, Toronto.

148. Ontario Ministry of Education (2009) Equity and inclusive education in Ontario schools. Guidelines for policy development and implementation. Queen's Printer for Ontario, Toronto.

149. OWP/P Architects, VS Furniture, Bruce Mau Design (2010) The third teacher: 79 ways you can use design to transform teaching and learning. Abrams, New York, NY.

150. Casella R (2003) Zero tolerance policy in schools: Rationale, consequences, and alternatives. Teachers College Record 105 872-892.
151. Kang-Brown J, Trone J, Fratello J, et al. (2013) A generation later: What we've learned about zero tolerance in schools. Vera Institute of Justice 1-10.

152. Boyd S (2012) Well-being at school: Building a safe and caring school climate that deters bullying.

153. National School Climate Council (2007) National school climate standards: Benchmarks to promote effective teaching, learning and comprehensive school improvement.

154. National School Climate Council (2010) The school climate challenge: Narrowing the gap between school climate research and school climate policy, practice guidelines and teacher education policy.

155. Connecticut General Assembly, Commission on Children (2011) Anti-bullying bill becomes law. 